\title{
AFCI Glovebox Radiological Release - Evaluation, Corrective Actions and Testing
}

G. H. Borschel, M. W. Lounsbury \& FMF Operators, J. J. Lopez, L. L. Burke, R. L. Case, J. D. Johnston \& FMF HPTs, J. A. Cannon, and M. W. Borland

December 2015

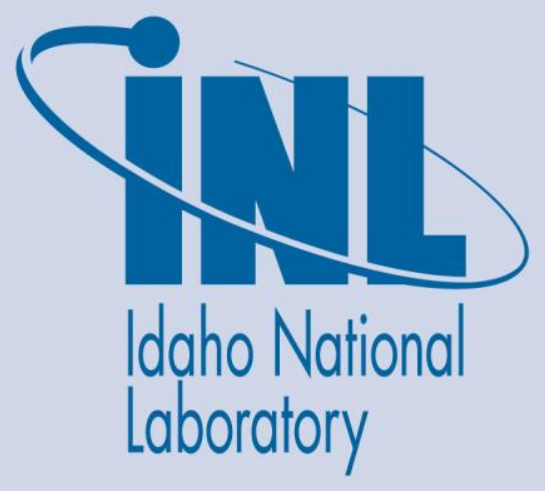

The INL is a U.S. Department of Energy National Laboratory operated by Battelle Energy Alliance

THIS DOCUMENT HAS BEEN APPROVED FOR EXTERNAL RELEASE AND CAN BE DISTRIBUTED BEYOND THE INL 


\section{DISCLAIMER}

This information was prepared as an account of work sponsored by an agency of the U.S. Government. Neither the U.S. Government nor any agency thereof, nor any of their employees, makes any warranty, expressed or implied, or assumes any legal liability or responsibility for the accuracy, completeness, or usefulness, of any information, apparatus, product, or process disclosed, or represents that its use would not infringe privately owned rights. References herein to any specific commercial product, process, or service by trade name, trade mark, manufacturer, or otherwise, does not necessarily constitute or imply its endorsement, recommendation, or favoring by the U.S. Government or any agency thereof. The views and opinions of authors expressed herein do not necessarily state or reflect those of the U.S. Government or any agency thereof. 
INL/EXT-15-36996

Revision 0

\section{AFCI Glovebox Radiological Release - Evaluation, Testing, and Corrective Actions}

G. H. Borschel, M. W. Lounsbury \& FMF Operators, J. J. Lopez, L. L. Burke, R. L. Case, J. D. Johnston \& FMF HPTs, J. A. Cannon, and M. W. Borland

December 2015

Idaho National Laboratory Idaho Falls, Idaho 83415

http://www.inl.gov

Prepared for the

U.S. Department of Energy

Office of Nuclear Energy

Under DOE Idaho Operations Office

Contract DE-AC07-05ID14517 


\title{
AFCI Glovebox Radiological Release - Evaluation, Testing, and Corrective Actions
}

\author{
INL/EXT-15-36996 \\ Revision 0
}

December 2015

\section{Approved by:}

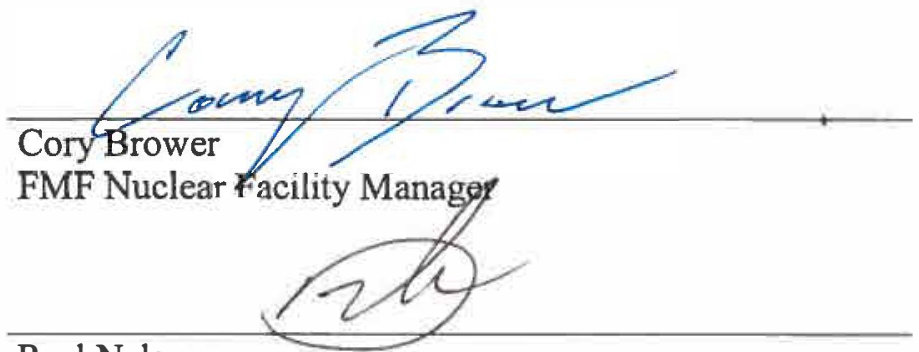

Paul Nelson

MFC Radiological Controls Manager

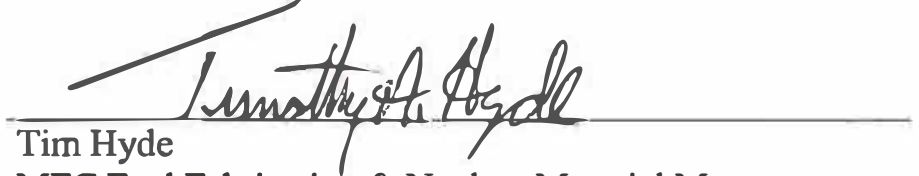

MFC Fuel Fabrication \& Nuclear Material Management

Director
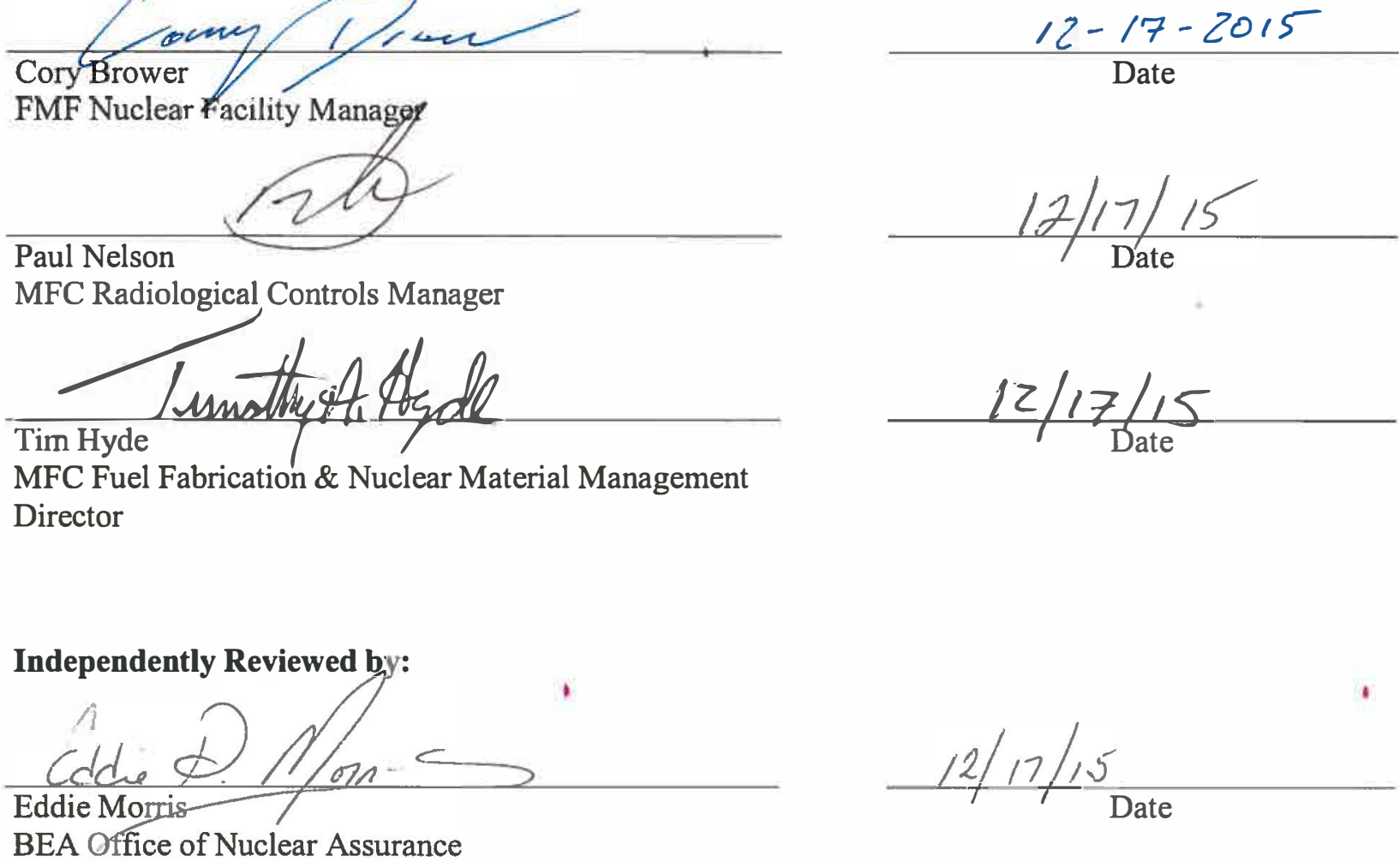


\section{CONTENTS}

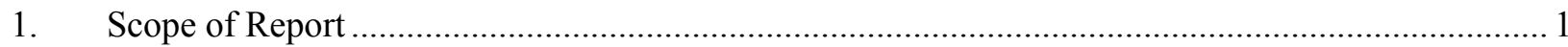

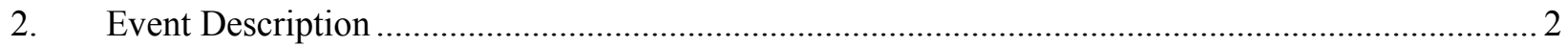

3. Background Information - Radiological Materials and Activity Descriptions .............................. 3

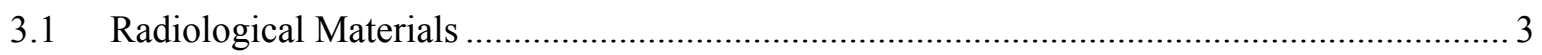

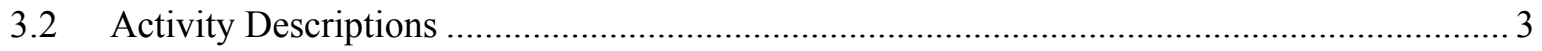

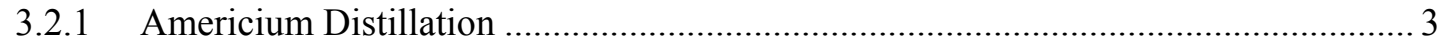

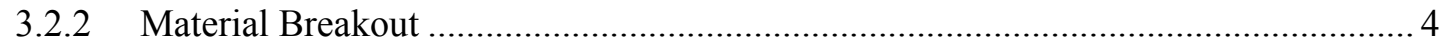

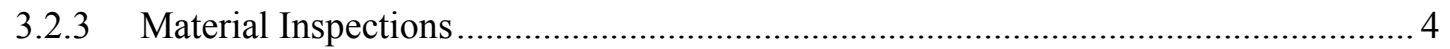

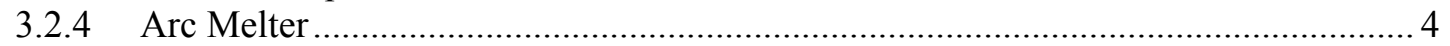

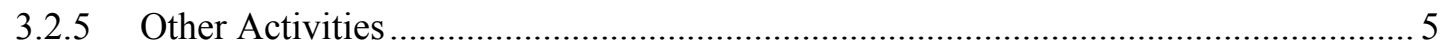

3.3 Activities Performed Prior to and During Event Timeframe …......................................... 5

4. Background Information - AFCI Glovebox and Associated Equipment Description ....................... 8

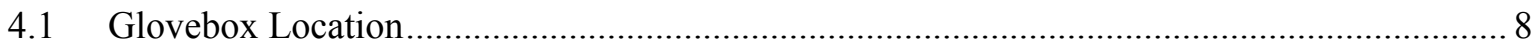

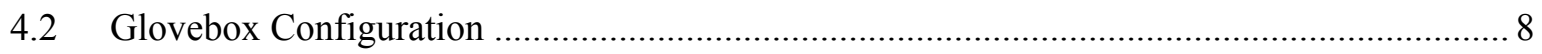

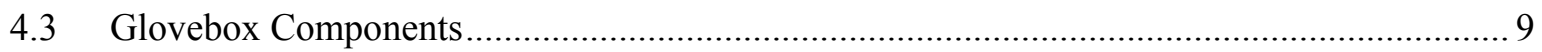

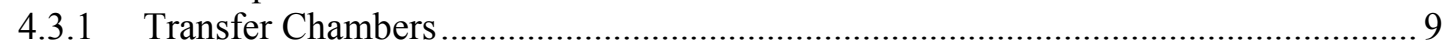

4.3.2 AFCI Glovebox Windows and Glove Ports ........................................................... 10

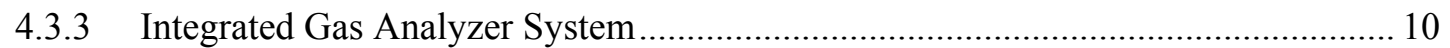

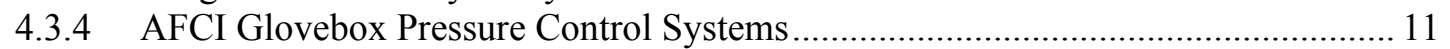

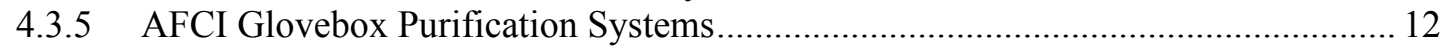

4.3.6 AFCI Glovebox Furnace Suspect Exhaust System ................................................ 12

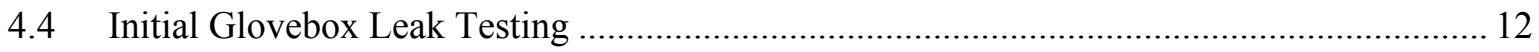

5. Evaluation of Glovebox Confinement Performance and Corrective Actions................................ 14

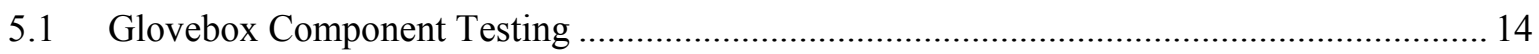

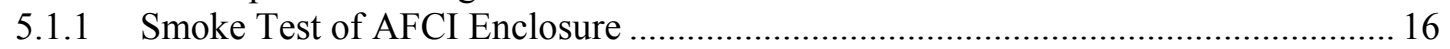

5.1.2 Oil Sample from Gas Exhaust System Vacuum Pump (V3-PMP-114) ...................... 16

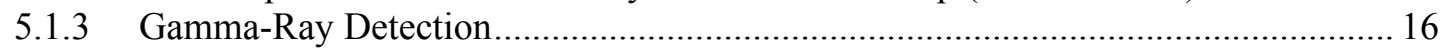

5.1.4 Americium Distillation Furnace Exhaust Line Integrity Checks ............................. 17

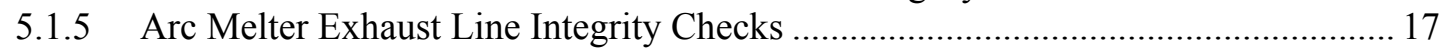

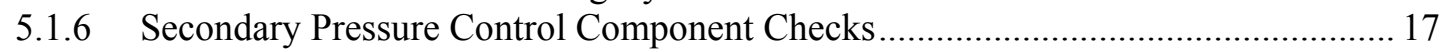

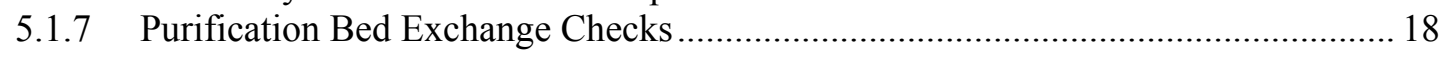

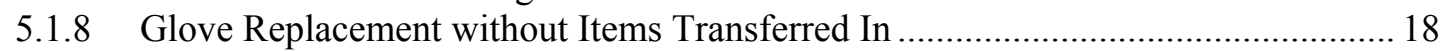

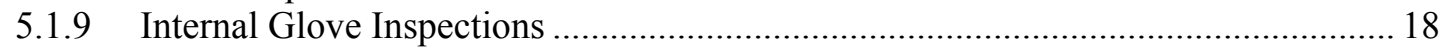

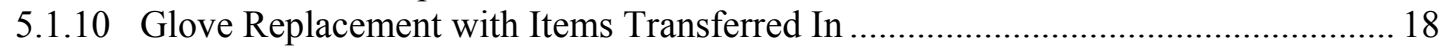

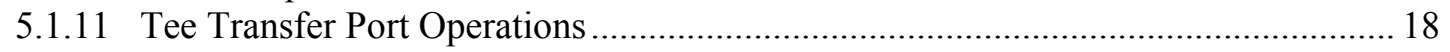

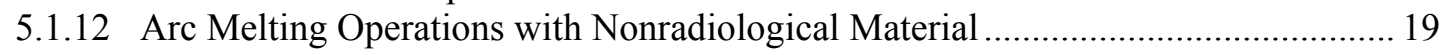

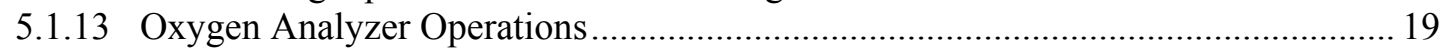

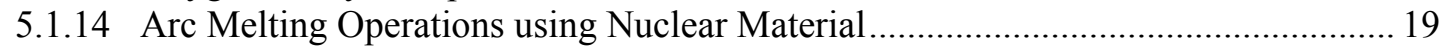

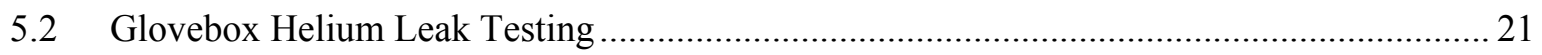

5.3 Glovebox Research Operations after Leak Repairs ........................................................ 22

5.4 Evaluation of Glovebox Performance and Corrective Actions ........................................... 23 


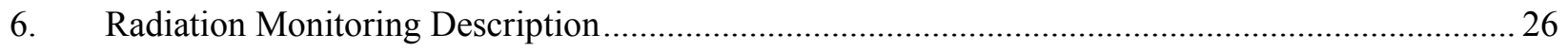

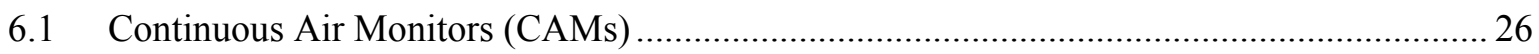

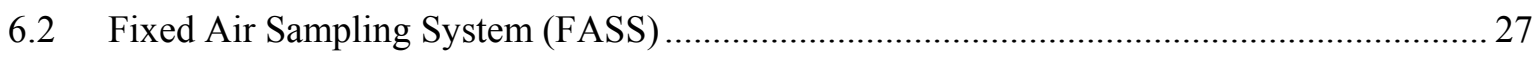

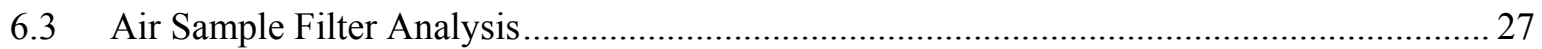

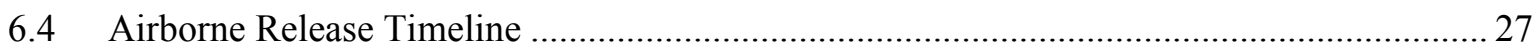

7. Evaluation of Radiation Monitoring Performance and Corrective Actions .................................. 30

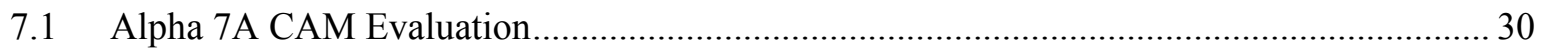

7.2 Air Flow and Air Monitoring Locations Evaluation ....................................................... 32

7.3 Surface Contamination Surveys Evaluation................................................................. 33

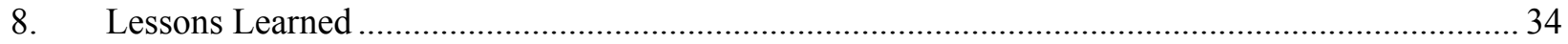

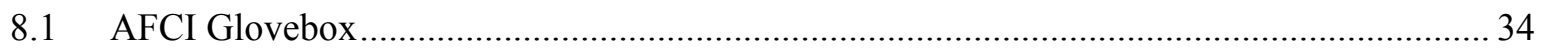

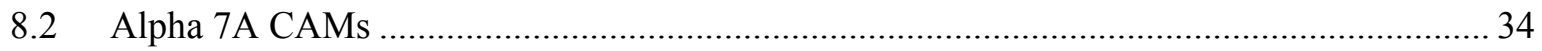

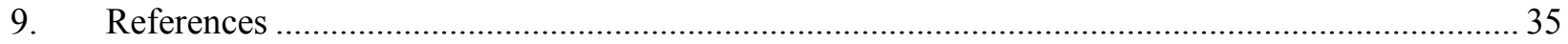

\section{FIGURES}

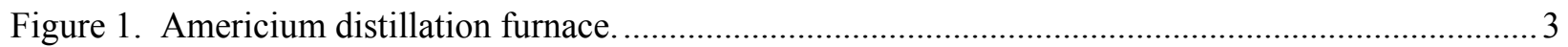

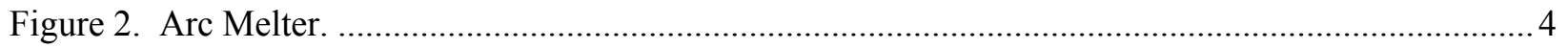

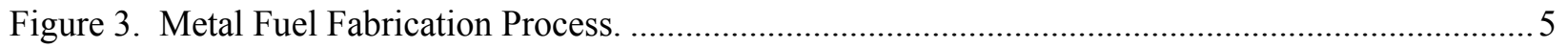

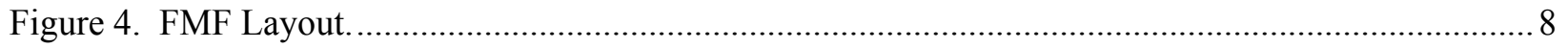

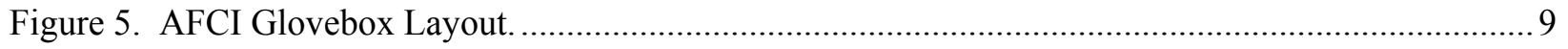

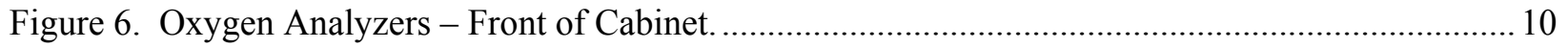

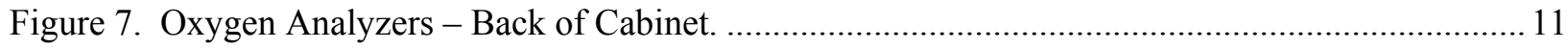

Figure 8. AFCI Enclosure and Fixed CAM and Job Specific CAM/Air Sampler Locations. ................... 15

Figure 9. Welding Lead Feedthroughs for Arc Melter (Top of Compartment A). ................................. 20

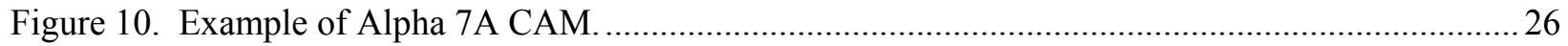

Figure 11. CAM algorithm shifting the Po-218 peak fit to Am-241 on 8-27-14 .................................... 30

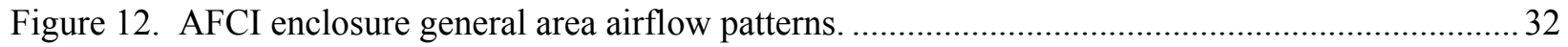

\section{TABLES}

Table 1. Summary of AFCI glovebox compartment functions............................................................... 9

Table 2. Glovebox System Leaks Identified by Helium Leak Testing. ...................................................2 22

Table 3. Approximate Airborne Radioactivity Release Periods and CAM Alarm Status ........................28

Table 4. Poor Fit and Slow Concentration Alarm Responses Summarized from TPR-7638, Rev. 6........ 31 


\section{APPENDICES}

Appendix A - Glovebox Tests or Activities, Results, and Conclusions ...................................................37

Appendix B - AFCI Glovebox Components Identified During Helium Leak Testing ............................ 42 


\section{ACRONYMS}

AFCI Advanced Fuel Cycle Initiative

Am Americium

ARA Airborne Radioactivity Area

BEA Battelle Energy Alliance

CAM Continuous Air Monitor

CED Committed Effective Dose

cpm counts per minute

CRL Central Research Laboratories

DAC Derived Air Concentration

DSA Documented Safety Analysis

$\mathrm{Du} \quad$ Depleted Uranium

dpm disintegrations per minute

ECAR Engineering and Calculation Analysis Report

FMF Fuel Manufacturing Facility

HPT Health Physics Technician

INL Idaho National Laboratory

LAW Large Area Wipe

LI Laboratory Instruction

LRD Laboratory Requirements Document

LWP Laboratory Wide Procedure

MCP Management Control Procedure

MDA Minimum Detectable Activity

MFC Materials and Fuels Complex

mrem millirem

Np Neptunium

PDD Program Description Document

PLN Plan

PMJ Preventive Maintenance Justification

$\mathrm{Pu} \quad$ Plutonium

RWP Radiation Work Permit

TEV Technical Evaluation

TPR Technical Procedure

TRU Transuranic

U Uranium

$\mathrm{Zr} \quad$ Zirconium 


\section{AFCI Glovebox Radiological Release - Evaluation, Testing and Corrective Actions}

\section{Scope of Report}

This report documents the results of the investigation into the releases of airborne radioactivity that occurred in the Advanced Fuel Cycle Initiative (AFCI) glovebox enclosure (room) located in the Fuel Manufacturing Facility (FMF) at the Idaho National Laboratory (INL) in late August and early September, 2014. The report documents the identified issues and associated corrective actions taken as well as providing lessons learned.

The investigation activities identified two primary issues:

- The AFCI glovebox confinement was compromised providing a pathway for airborne radiological contamination releases, particularly when arc melting activities with transuranics containing americium (Am)-241 were performed.

- The Continuous Air Monitors (CAMs) located in the AFCI enclosure did not correctly identify Am241 (predominant isotope in release) and provided non-conservative responses.

Testing activities on the AFCI glovebox confinement systems were developed in PLN-4861, "AFCI Glovebox Testing Plan," and were performed using LI-692, "AFCI Glovebox Component Testing and Surveys." It was later determined that additional testing in the form of helium leak testing was required to pinpoint confinement breaches. Helium leak testing activities were performed using TPR-13438, "Leak Test Procedure." Test results (including radiological air monitoring data) and glovebox confinement system repairs are discussed in Section 5 and summarized in Appendices A and B. Corrective actions are also discussed in Section 5.

CAM performance was evaluated in detail in report INL/INT-14-00118, "Alpha 7A Continuous Air Monitor Data Reconstruction for Advanced Fuel Cycle Initiative Glovebox Airborne Radioactivity Release." Identified issues and corrective actions are discussed in Section 6. 


\section{Event Description}

The Fuel Manufacturing Facility (FMF) is located at the Materials and Fuels Complex (MFC) on the Idaho National Laboratory (INL) site. The current mission includes fuel fabrication research and development. Handling and processing of uranium-bearing, plutonium-bearing, and other transuranic (TRU) materials is performed in the Advanced Fuel Cycle Initiative (AFCI) glovebox located in the AFCI enclosure (room) of FMF.

Activities performed in the AFCI enclosure during August 26 to 28, 2014 consisted of arc melting to form transuranic alloys for fuel fabrication activities and transuranic material breakout within the AFCI glovebox. Maintenance in the form of glovebox glove replacement and a gauge replacement was also completed. No contamination was found on personnel, PPE, or equipment as determined by routine surveys, direct scans and large area wipes (LAWs). However, there were instances of CAM alarms (concentration and "poor-fit") in the AFCI enclosure which at the time were viewed as maintenance trouble alarms. In the past at MFC, "poor-fit" alarms were typically caused by environmental interference (radio frequency signals, light leaks, dust) so the procedural requirement at the time of the event was to change filters to allow the CAM to reset.

On September 24, 2014, during review of routine "delayed" counting of air sample filters from radiological air monitoring equipment, transuranic material was discovered on air sample filters collected from the FMF AFCI enclosure during the period from August 26 through August 28, 2014. (Delayed counts are performed after a period of time, typically at least 7 days, to allow radon/thoron isotopes to decay.) Two of the air sample filters in question were from the AFCI enclosure fixed continuous air monitor (CAM) and two were from the portable low volume ("giraffe") air sampler. Since the source of contamination was unknown, Radiological Controls and FMF management conservatively established the FMF AFCI enclosure room as an airborne radioactivity area (ARA) on September 24, 2014. Bioassay samples were obtained from 15 personnel who were either working under the Radiation Work Permit (RWP) for the AFCI glovebox or had entered the AFCI enclosure during the timeframe in question. Results indicated nine individuals with low levels of internal contamination consisting of americium (Am)-241 as the primary isotope. The maximum individual CED (committed effective dose) was less than 100 mrem. (It should be noted under federal law bioassay monitoring is not required for individuals expected to receive less than 100 mrem per year.) Bioassay samples were also obtained from six randomly selected personnel who entered the FMF facility during the timeframe in question. No internal dose was identified for those personnel.

Am-241 was identified as the primary radionuclide present in the airborne release based on subsequent review of data from the air sample filter analyses, CAM stored electronic data history, and bioassay results. Airborne releases on August 26, August 27, August 28 and a minor release on September 3 were identified by analyzing the CAMs' stored electronic data history. The CAM alarms (concentration or "poor fit") for the time period in question were determined to have occurred shortly after the identified releases. It was identified in some cases that the curve fitting algorithm in the CAM software treated the Am-241 as a radon progeny (background) which eventually resulted in a "poor fit" alarm. 


\section{Background Information - Radiological Materials and Activity Descriptions}

\subsection{Radiological Materials}

Activities in the AFCI glovebox primarily consist of handling transuranic (TRU) material for nuclear fuel fabrication or nuclear fuel feedstock preparation. The Documented Safety Analysis (DSA) ${ }^{1}$ for FMF has a control on the types and quantities of radioactive process material allowed in the AFCI glovebox. Materials consist of uranium ${ }^{\mathrm{a}}$, neptunium $(\mathrm{Np})-237$, plutonium $(\mathrm{Pu})$ isotopes $^{\mathrm{b}}$, americium $(\mathrm{Am})-241$, and Am-242m.

\subsection{Activity Descriptions}

The AFCI glovebox was designed to be used for various transuranic fuel development activities. Activities include americium distillation; alloy production (arc melting); ceramic fuel mixing, pressing, and sintering; material breakout; fuel loading and welding for experiment assembly.

Just prior to and during the event timeframe, activities in the AFCI glovebox included americium distillation, material breakout, material inspections, and arc melting. These activities are discussed in more detail below.

\subsubsection{Americium Distillation}

Most americium available to research programs is not pure. It is usually mixed with plutonium and/or other impurities and may be in either metallic or oxide form. To produce pure metallic americium, a distillation apparatus is used inside the glovebox to distill the metallic americium from the plutonium. The furnace is shown in Figure 1. During distillation operations the americium feedstock, up to approximately 3 grams, is loaded into the crucible and heated under a vacuum to reduce and/or evaporate the feedstock and drive the americium up to a cooler region in the crucible or onto the cold finger. After the process is finished the crucible and cold finger assembly is disassembled and the americium is retrieved by cutting the americium out of the crucible using a reaming tool. During the heating and evaporation process a vacuum line (connected to a vacuum system outside of the glovebox) is attached to the crucible. This vacuum line has two 0.2 micron filters, one inside of the glovebox and another outside of the glovebox prior to the vacuum pump.

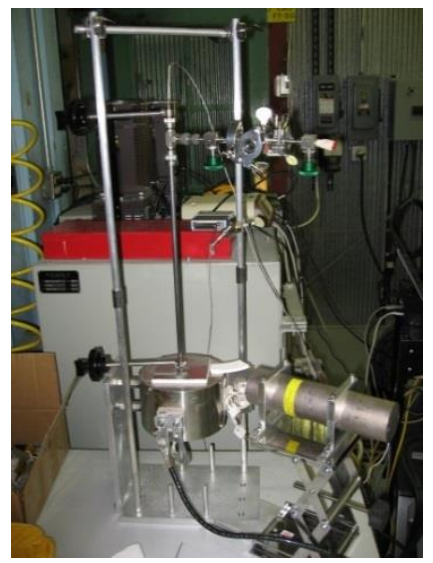

Figure 1. Americium distillation furnace.

\footnotetext{
${ }^{\text {a }}$ Uranium resulting from $\mathrm{U}-233$ production activities is not permitted.

${ }^{\mathrm{b}}$ Plutonium resulting from $\mathrm{Pu}-238$ production activities is not permitted. This allows the $\mathrm{Pu}$ in the glovebox to consist of any mixture of weapons- or reactor-grade $\mathrm{Pu}$ isotopes.
} 


\subsubsection{Material Breakout}

Other research facilities located at MFC have radioactive material mass limits lower than those of the FMF, therefore material stored in FMF is frequently divided into smaller quantities before it can be used or transferred to another facility. The material breakout activities involve transferring the material container into the glovebox, then unpacking and dividing the material either through separating pieces or cutting pieces. The FMF DSA requires the material to be packaged in closed metal containers when transferred into or out of the glovebox.

\subsubsection{Material Inspections}

A number of samples from previous experiments and fuel fabrication campaigns have been stored in FMF. Material inspections are performed to ensure samples maintain their integrity and to consolidate samples as needed. Material inspections are similar to the breakout activities in that material containers are brought into the glovebox and unpackaged. The samples are visually examined to determine the extent of oxidation and integrity of the packaging. If samples are determined to be usable, they are repackaged into appropriate containers (usually constructed of stainless steel). If the samples have been excessively oxidized or were originally packaged in poly bottles/bags and are degraded beyond usability they are consolidated for eventual disposition.

\subsubsection{Arc Melter}

The arc melter is an apparatus in which an electric arc between a non-consumable tungsten electrode and the work piece/hearth is used to heat/melt the work piece for a very short time frame, generally on the order of 10-15 seconds. Figure 2 shows the arc melter used in the AFCI glovebox. The arc melter has been used for several years in the AFCI glovebox for melting and consolidating a number of uranium and transuranic bearing alloys. In order to ensure a clean melting atmosphere an argon purge line is attached to the arc melter. The arc melting chamber is partially open to the glovebox atmosphere but, to preclude over pressurization of the arc melting chamber, an exhaust line is also connected to the arc melting chamber through which gas is exhausted from the chamber. The exhaust line has two 0.2 micron filters, one inside of the glovebox and one outside of the glovebox prior to the vacuum pump. Arc melting is used as part of the process for metal fuel fabrication in the AFCI glovebox as shown in Figure 3.

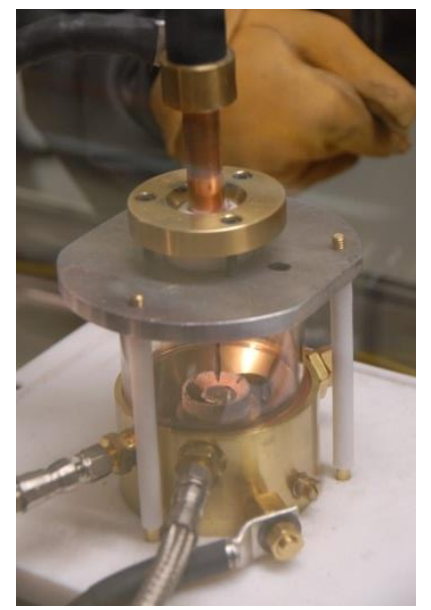

Figure 2. Arc Melter. 


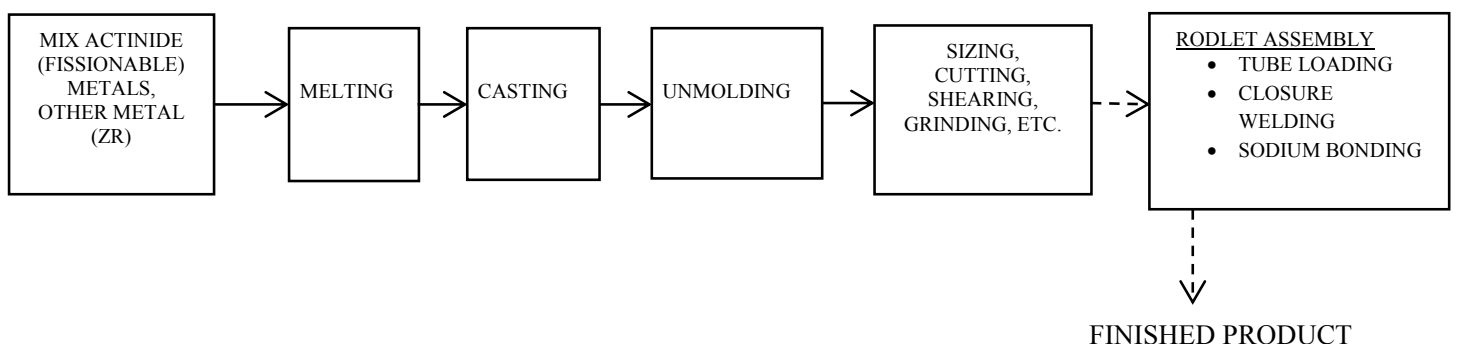

Figure 3. Metal Fuel Fabrication Process.

\subsubsection{Other Activities}

Fuel pellets are fabricated using tube and sintering furnaces, sieves, mill, presses, and other equipment. Fuel rodlets are assembled in the AFCI glovebox by inspecting and loading fuel pellets into tubes and seal welding the tube ends. These activities were not performed prior to or during the event timeframe.

\subsection{Activities Performed Prior to and During Event Timeframe}

Based on FMF facility $\operatorname{logs} s^{2,3}$, FMF Radiological Controls $\log s^{4}$, Critique Report ${ }^{5}$, PLN-4861 ${ }^{6}$, and INL/MIS-14-33725 ; the following activities were performed in the AFCI glovebox or AFCI enclosure prior to and during the event timeframe:

Note - All AFCI glovebox equipment and radiological controls equipment were current on preventive maintenance (PMs) and calibrations at the start of this timeline.

- Week of May 5, 2014 - Several americium distillation runs were completed.

- May 15, 2014 - Monthly calibration and response check of AFCI glovebox hydrogen monitor was completed.

- May 19, 2014 - Distillated americium was recovered from the distillation hardware.

- May 21, 2014 - Waste was removed from the AFCI glovebox.

- Mid to late May, 2014 - Plutonium feedstock breakout activity was completed.

- Early June, 2014 - Transuranic bearing alloys from the FMF vault were retrieved and inspected.

- Late June to August, 2014 - Maintenance outage in FMF

- The majority of the maintenance was not associated with the AFCI glovebox. Based on the FMF facility log, the following AFCI glovebox maintenance was performed:

- 12 month sintering furnace pressure calibration

- 12 month argon supply to furnace and AFCI glovebox pressure calibration

- 12 month AFCI glovebox pressure instruments [calibration]

- Monthly calibrations and response checks of AFCI hydrogen monitor

- 12 month AFCI glovebox magnehelic gauges and pressure transducers [calibration]

- August 11 - 14, 2014 - Radiological material segregation was performed. Changed out a glove in the glovebox. Radiological material consolidation was performed. 
- August 18, 2014 - AFCI glovebox cleanout and radiological material transfer was completed.

- August 20, 2014 - Radiological material packaging operations in the AFCI glovebox was completed. Changed out a glove in the glovebox.

- August 21,2014 - Radiological material transferred from the AFCI glovebox to storage. The monthly calibration and response check of AFCI hydrogen monitor was performed.

- Late August, 2014 - Glovebox was reconfigured for arc melting. The furnace power cables from the glovebox power feedthroughs (located inside glovebox) were disconnected from the americium distillation furnace and were connected to the arc melter system.

- August 25, 2014 - Preparatory work for AFCI arc melting was completed. Practiced arc melting performed using nonradiological material.

Note-Arc melting had not been performed in the AFCI glovebox for several years prior to this evolution. Arc melting was performed with combinations of $\mathrm{Pu}, \mathrm{Am}, \mathrm{Np}$ and zirconium in late August and September, 2014.

- August 26, 2014 - Initiated repair for gauge on transfer port (gauge needle was sticking). Changed out a glove in the glovebox. Arc melting with radiological material was performed.

AFCI fixed CAM alarmed. No surface contamination was found above LRD-15001 ${ }^{14}$ Table 2-2 limits and alpha hand monitors (friskers) in the room showed no indication of elevated background or alarm. The fixed CAM filter was removed for counting and replaced with a new filter. The AFCI enclosure was released for entry. The facility was closed midday and soon thereafter the portable CAM alarmed (poor fit).

Note - Per LRD-15001 for the isotopes of concern in FMF, a surface is considered contaminated if either the removable or the total surface contamination exceeds the values listed in Table 2-2.Values less than the Table 2-2 limits are recorded as such on the survey reports (i.e., removable contamination as $<1000 \mathrm{dpm} / 100 \mathrm{~cm}^{2}$ for beta/gamma and $<20 \mathrm{dpm} / 100 \mathrm{~cm}^{2}$ for alpha, total [removable + fixed] as $<5000 \mathrm{dpm} / 100 \mathrm{~cm}^{2}$ beta gamma and $<100 \mathrm{dpm} / 100 \mathrm{~cm}^{2}$ alpha).

- August 27, 2014 - Responded to portable CAM alarm (poor fit from previous day) upon entry to AFCI enclosure in the morning. No contamination above LRD-15001 Table 2-2 limits was found and alpha hand monitors (friskers) in the room showed no indication of elevated background or alarm. The portable CAM filter was removed for counting and replaced with a new filter. The AFCI enclosure was released for entry. Changed out a glove to transfer tools into the glovebox. AFCI fixed CAM software was upgraded. Gauge on tee transfer port was replaced. Arc melting with radiological materials was performed. The portable CAM alarmed (poor fit). No contamination above LRD-15001 Table 2-2 limits was found. The portable CAM filter was removed for counting and the CAM was placed out of service due to multiple false alarms.

- August 28, 2014 - Arc melting with radiological materials was performed. Fixed CAM alarmed (poor fit) later when facility was unoccupied.

- September 2,2014 - Upon return from the weekend and holiday, the fixed CAM filter was removed for counting and replaced with a new filter. Radiological material was opened in the AFCI glovebox.

- September 3, 2014 - Fixed CAM was in alarm upon return to work in the morning which was identified as "spurious." Smears identified no contamination above LRD-15001 Table 2-2 limits and alpha hand monitors (friskers) in the room showed no indication of elevated background or alarm. The CAM filter was removed for counting and replaced with a new filter. The AFCI enclosure was released for entry. Transferred radiological material into the AFCI glovebox via glove change out. 
- September 4, 2014 - AFCI miscellaneous operations were conducted.

- September 8, 2014 - AFCI arc melting preparations were performed.

- September 9,2014-AFCI miscellaneous operations were conducted. Changed out a glove in the glovebox.

Note-Arc melting was suspended while support equipment was being fabricated during the second and third weeks of September.

- September 18, 2014 - Three month oxygen analyzer system calibration was performed.

- September 23, 2014 - AFCI arc melting operations were performed. Changed out a glove in the glovebox.

- September 24, 2014 - AFCI arc melting operations were performed. Work in the AFCI glovebox was curtailed when transuranic contamination was identified on the delay counting of air sample filters from August 25 to September 2. The AFCI enclosure was established as an ARA. Values were later determined to range from 39 DAC-hr to $68 \mathrm{DAC}-\mathrm{hr}$ (861.4 dpm alpha to $2065.0 \mathrm{dpm}$ alpha). ${ }^{12}$ 


\section{Background Information - AFCI Glovebox and Associated Equipment Description}

\subsection{Glovebox Location}

The ACFI glovebox is located on the north side of the north workroom. The north workroom has been partitioned into two main rectangular areas, and the area housing the AFCI glovebox is the AFCI enclosure. The dimensions of the enclosure are approximately $11-\mathrm{ft}$ (north-south) by $44-1 / 2-\mathrm{ft}$ (east-west). Doors that provide access into the ACFI enclosure are located at both east and west ends.

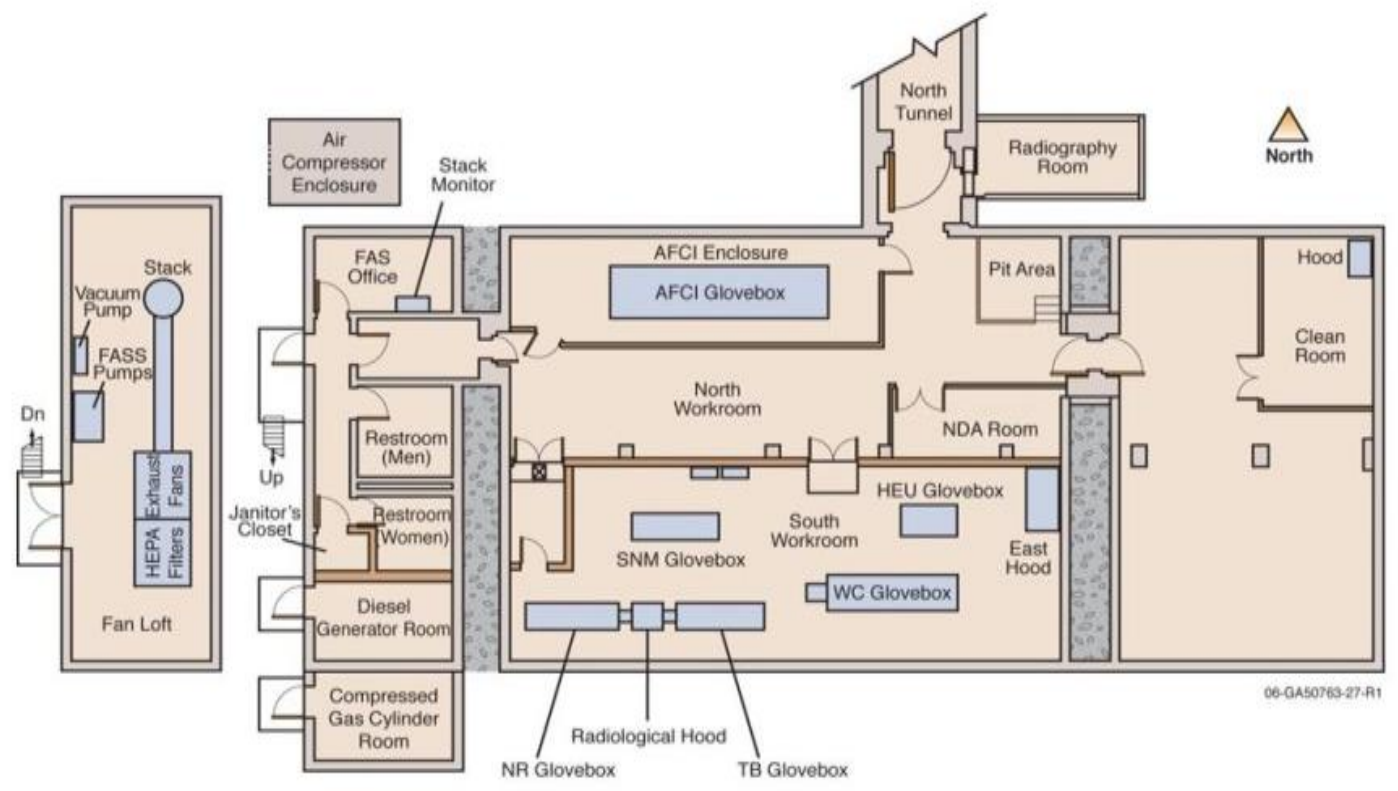

Figure 4. FMF Layout.

\subsection{Glovebox Configuration}

The AFCI glovebox is composed of two independently-operated (but interconnected) glovebox systems. The first glovebox system is composed of two double-sided gloveboxes attached together via a 12$1 / 2$-inch $\times 12-1 / 2$-inch portal. These two are referred to as the Wilkins gloveboxes. These two gloveboxes comprise compartments A and B of the AFCI glovebox and house the equipment used for americium distillation, arc melting, and fuel pellet fabrication.

The second glovebox system is a double-sided glovebox referred to as the VAC glovebox. The VAC glovebox is divided into three compartments: C, D, and E. Compartments C, D, and E house the equipment used for fuel rodlet fabrication. 


\section{AFCl Enclosure}

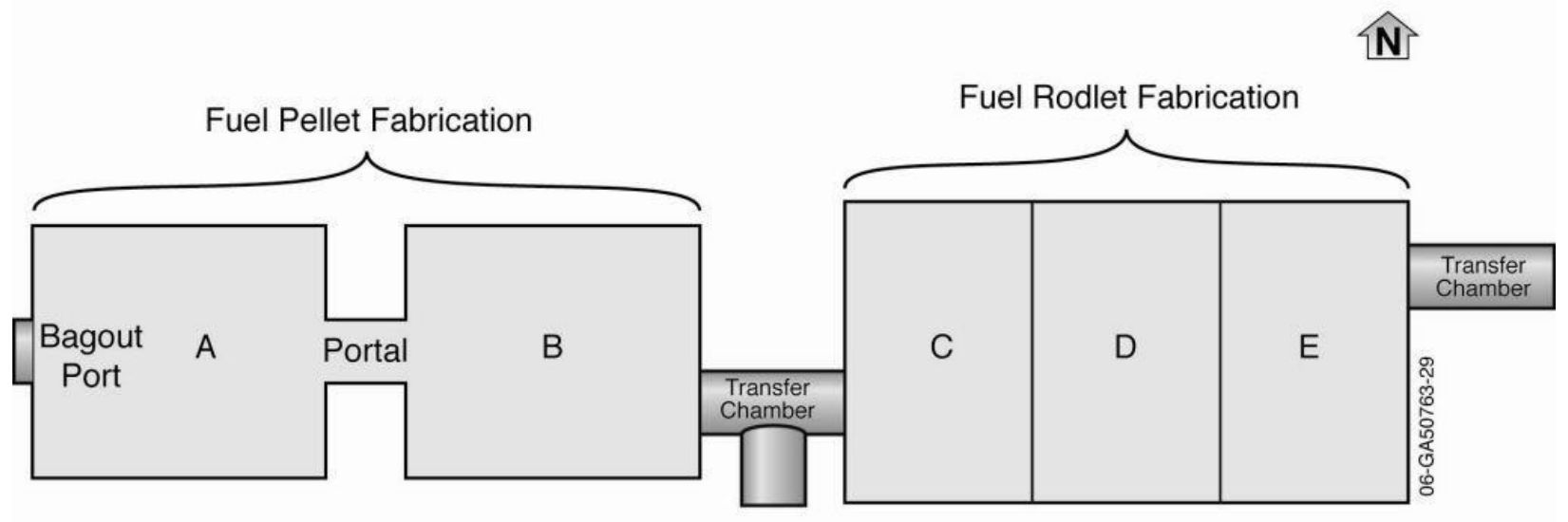

Wilkins Gloveboxes

VAC Glovebox

Figure 5. AFCI Glovebox Layout.

The processing functions in each compartment are listed in Table 1.

Table 1. Summary of AFCI glovebox compartment functions.

\begin{tabular}{|c|l|}
\hline Compartment & \multicolumn{1}{|c|}{ Function } \\
\hline A and B & $\begin{array}{l}\text { Fuel pellet fabrication using tube and sintering furnaces, sieves, mill, presses, and } \\
\text { other equipment. Americium distillation and alloy production (arc melting). }\end{array}$ \\
\hline C & $\begin{array}{l}\text { Handling, final inspection, weighing, staging, and loading of finished fuel pellets } \\
\text { into the tubes (to assemble rodlets). }\end{array}$ \\
\hline $\mathrm{D}$ & $\begin{array}{l}\text { Closure welder for seal welding of rodlets and (optional) mass spectrometry leak test } \\
\text { of assembled rodlet. }\end{array}$ \\
\hline $\mathrm{E}$ & Clean buffer area for material transfer. \\
\hline
\end{tabular}

\subsection{Glovebox Components}

\subsubsection{Transfer Chambers}

15-in. inner diameter (ID) "tee" transfer port (anti-chamber) connects compartment B (Wilkins glovebox) to compartment $\mathrm{C}$ (VAC glovebox). This transfer port provides a transfer path for materials between the Wilkins and VAC gloveboxes while allowing the two glovebox systems to operate with different inert atmosphere mixtures. This transfer port also aids in maintaining lower contamination levels in the VAC glovebox than in the Wilkins gloveboxes. A second 15-in. ID transfer chamber is located on the east end of the VAC glovebox (compartment E) for transfers in and out of the VAC glovebox. Both transfer ports/chambers can be purged via a vacuum pump to the facility suspect exhaust system and filled with the same inert gas mixture as the atmosphere of either glovebox. Through a series of purge and fill cycles, transfers can be made into, out of, or between gloveboxes, while maintaining the purity of the respective glovebox atmospheres. There is also a 12-in. bag-out port located on the west end of the Wilkins glovebox (compartment A). 


\subsubsection{AFCl Glovebox Windows and Glove Ports}

Eight polycarbonate windows (3/8-in.-thick) are located around the perimeter of the Wilkins gloveboxes, one for each work station. Six polycarbonate windows (1/2-in.-thick) are also located around the perimeter of the VAC glovebox, one on either side of each compartment. Long, narrow polycarbonate windows, primarily for providing light, are located in the tops of each compartment. All confinement boundary windows are flange-mounted using wrap-around neoprene gaskets. Shield windows are installed on the exterior of the polycarbonate confinement windows of compartments $\mathrm{A}, \mathrm{B}$, and $\mathrm{C}$ when needed for metal fuel fabrication. Shield windows are fabricated of 12-mm-thick leaded glass.

A total of sixteen 8-in.-diameter glove ports are mounted at an elevation of about $50 \mathrm{in}$. around the Wilkins gloveboxes (eight each box) to provide eight work stations. An additional 16 glove ports are located at an elevation of about $70 \mathrm{in}$. to allow access to the upper areas of the glovebox. A total of twelve 8 -in.-diameter glove ports are mounted around the VAC glovebox to provide two work stations (one on each side) in each compartment.

\subsubsection{Integrated Gas Analyzer System}

The purity of the AFCI glovebox atmosphere is monitored by an integrated gas analyzer instrumentation system. The integrated system is provided to measure levels of oxygen, helium, nitrogen, and hydrogen in the AFCI glovebox atmosphere.

The overall system consists of two oxygen analyzers, one helium analyzer, and one nitrogen/hydrogen analyzer. The system consists of gas sample, return, and exhaust lines; the individual analyzers, pumps, flow indicators, and valves located in the AFCI enclosure.

A single sample line from each glovebox (Wilkins or VAC) provides the sample, which is directed to selected analyzers by the appropriate valve lineup. The sampling system is constructed primarily of soldered transfer lines to minimize leakage. Each sample line has one 0.2 micron filter inside of the glovebox. Each of the oxygen analyzers is served by a dedicated vacuum pump. Incorporation of an eight-way valve into the system provides redundant oxygen analyzing capability so that either analyzer can be connected to either of the two gloveboxes while ensuring the sample is returned to the same glovebox.

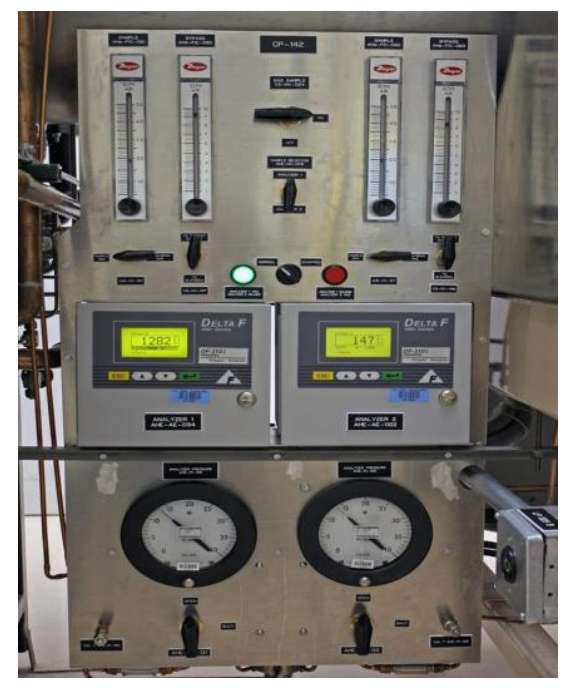

Figure 6. Oxygen Analyzers - Front of Cabinet. 


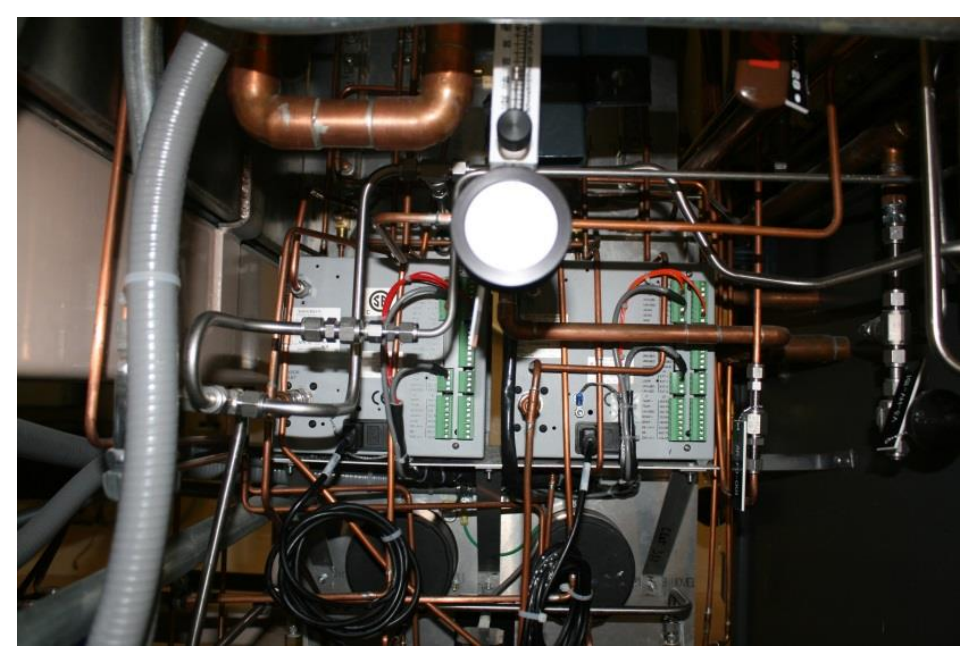

Figure 7. Oxygen Analyzers - Back of Cabinet.

\subsubsection{AFCl Glovebox Pressure Control Systems}

Pressure control systems are provided to ensure the quality of the AFCI glovebox atmosphere for process control. The three systems (primary, secondary, and tertiary) are described briefly below.

The primary pressure control system is provided for each of the gloveboxes (Wilkins and VAC). The primary pressure control system is housed within the respective purification system for the Wilkins and the VAC gloveboxes. The systems operate to maintain glovebox pressure at desired set points, typically in the range -0.5 in. to -1.0 in. $\mathrm{H}_{2} \mathrm{O}$. If the glovebox pressure falls out of range, the makeup gas (argon, helium, or any mix of the two) gas valve opens to increase glovebox pressure (if pressure is too low), or the vent valve opens to a vacuum pump, which decreases glovebox pressure (if pressure is too high). Glovebox pressure can also be adjusted manually by a foot switch on the primary pressure control system. Excess gas is vented to the suspect exhaust. The control system also allows for controlled purging of the glovebox with argon, based on a purge time (duration) or desired oxygen level.

A secondary pressure control system is provided for each of the gloveboxes (Wilkins and VAC) as a backup to the primary pressure control systems. The secondary system can also be used to assist the primary system in controlling the glovebox pressure. The system operates to maintain glovebox pressure at desired setpoints, typically in the range -0.2 to -2.5 in. $\mathrm{H}_{2} \mathrm{O}$. Similar to the primary system, the secondary system supplies gas (argon, helium, or any mix of the two) at low glovebox pressure indications or vents excess gas from the glovebox at high glovebox pressure indications. The excess gas is vented to the suspect exhaust. Associated with the secondary system is a blower that maintains negative pressure in the glovebox. Actuation of the blower is controlled by system set points and a time delay. If a glovebox boundary failure occurs, the blower provides gas flow at $125 \mathrm{lfpm}$ face velocity into the glovebox. The control system has the capability to alarm when system set points are exceeded.

A tertiary pressure control system is provided for each glovebox (Wilkins and VAC). This system functions to protect the glovebox from collapsing (imploding or expanding) from a pressure spike in the event that the primary and secondary systems cannot maintain the pressure within specified ranges. The tertiary systems begin venting to the suspect exhaust at \pm 3.5 in. $\mathrm{H}_{2} \mathrm{O}$. Each system consists of one over-pressure and two under-pressure bubblers. If glovebox pressure is too high, gas (argon) is forced through the bubbler and into the suspect exhaust. If glovebox pressure is too low, then air is drawn into the glovebox through the bubbler. 


\subsubsection{AFCl Glovebox Purification Systems}

Purification systems are provided for both the Wilkins glovebox and the VAC glovebox. The purification systems are part of the primary pressure control systems. The purpose of the purification system is to maintain glovebox atmospheric quality (less than $50 \mathrm{ppm}_{2}$ ) by removing oxygen and moisture. Each purification system contains a vacuum pump, two purifier canisters, piping, valves, a 40 -cfm blower, instruments, and controls. The system is connected to the glovebox through a 1-1/2-in. recirculation line and isolation valves. During recirculation, the gas passes through a HEPA filter, one of the purifier canisters, and returns to the glovebox through another HEPA filter. The purifier canisters are alternated so that one may be regenerating while the other is in use.

Regeneration of the purification canister is initiated when glovebox impurity levels in the canister bed rise above $50 \mathrm{ppm} \mathrm{O}_{2}$. The regeneration gas for each purification system is supplied from premix gas bottles of an argon/hydrogen gas.

\subsubsection{AFCl Glovebox Furnace Suspect Exhaust System}

The overall AFCI glovebox system is connected to the glovebox suspect exhaust header, a 4-inch Schedule 40 pipe. The primary connections to that header are:

- Exhaust from the regeneration of the purification systems for both the Wilkins and the VAC gloveboxes

- $\quad$ Primary vent from the VAC glovebox

- A secondary vent and miscellaneous panel vents

- $\quad$ Argon sweep.

Off-gas from the tube and sintering furnaces is routed to this header via the furnace exhaust system, which consists of multiple valves, a solenoid interlock, and a blower. The arc melter argon purge and americium distillation furnace vacuum are also connected to the furnace exhaust system.

The furnace gas exhaust ties into the argon sweep, rather than directly into the glovebox header. The argon sweep dilutes the furnace gas exhaust and regeneration exhaust, both of which are sources of $\mathrm{H}_{2}$ in high concentrations. The system is designed to ensure that the $\mathrm{H}_{2}$ concentration in the glovebox exhaust is below $25 \%$ of the lower explosive limit (LEL) (i.e., $1 \%$ ). The glovebox exhaust header ties into the facility suspect exhaust header in the north workroom after flowing through the AFCI glovebox exhaust HEPA filter.

Gases from the primary and secondary pressure control systems go through a HEPA filter at the glovebox boundary. Other gas lines and penetrations have one 0.2 micron filter inside of the glovebox. Another 0.2 micron filter is located outside of the glovebox prior to the vacuum pump.

\subsection{Initial Glovebox Leak Testing}

The design, fabrication and installation description document for the AFCI glovebox ${ }^{8}$ provided the following information:

"The gloveboxes were initially leak tested at a pressure of 4 in. of water with at least $90 \%$ helium with a mass spectrometry leak detector with a sensitivity of at least $10^{-5} \mathrm{cc} / \mathrm{sec}$ (helium) sensitivity. Because the bubbler relief system is designed without any isolation valves all 
subsequent leak tests were performed in accordance with ASME B\&PVC, Section V, Article 10. For the re-tests, the gloveboxes shall be pressurized between +1.0 and +1.5 in. of water (relative to ambient) with a mixture of air and a minimum of $10 \%$ helium. There shall be no detectable leakage (individual leaks) from any weld or mechanical joint when tested with an instrument capable of detecting leaks down to $1 \times 10^{-5} \mathrm{cc} / \mathrm{sec}$. Leak tests shall be conducted at a temperature between 70 and $100^{\circ} \mathrm{F} . "$

"Support piping systems (except Plant Air and hydrogen) shall be leak tight to $1 \times 10^{-3} \mathrm{cc} / \mathrm{sec}$ for each leak."

"All penetrations shall meet the same leak test requirements established for the glovebox."

The glovebox was re-tested in place and turned over from construction in 2007. After completion of installation, there are no additional regulatory or standards requirements to perform helium leak testing on radiological gloveboxes. Component changeouts from this point forward were typically "bubble-tested" at the glovebox boundary for leaks. Per DOE-STD-1128 ${ }^{9}$, plutonium gloveboxes are normally maintained at a negative pressure to preclude the spread of contamination to occupied areas or the environment, therefore positively pressurizing the contaminated glovebox for leak testing is not considered a viable option. Based on discussions with facility management, there have been no major modifications to the glovebox after 2007. 


\section{Evaluation of Glovebox Confinement Performance and Corrective Actions}

\subsection{Glovebox Component Testing}

An event investigation was performed by BEA's Office of Nuclear Assurance (ONA). ${ }^{7}$ The investigation was unable to identify a direct cause of the airborne release. However, potential release scenarios were evaluated including sources outside of the AFCI glovebox. Sources external to the AFCI glovebox were ruled out.

AFCI glovebox oxygen and pressure levels recorded in the FMF facility $\operatorname{logs}{ }^{10}$ during the event timeframe were reviewed for indications of a confinement breach. No unexpected readings inside the glovebox were identified. However, it should be noted that the glovebox atmosphere is cycled through the purification system to remove oxygen. In addition, argon is regularly introduced as makeup due to the oxygen sampling system. These actions could mask a slow leak into the glovebox.

PLN-4861, "AFCI Glovebox Testing Plan," " was developed utilizing fuel fabrication researchers, facility operations personnel, radiological controls personnel and facility engineers to identify potential sources for an AFCI glovebox confinement breach. A series of exploratory tests were developed in an effort to recreate and/or identify the breach or breaches while maintaining normal negative pressure conditions within the glovebox. Corresponding work control was developed in the form of Laboratory Instruction (LI)-692, "AFCI Glovebox Component Testing and Surveys." "11 The following conditions were established for the tests:

- No fuel (i.e., radiological material) handling will be performed during testing except for final tests involving operation of the arc melter.

- Radiological smears for investigative purposes will use Whatman 1 and/or Millipore (Fluorpore) filters. Whatman 1 are the standard smears. However, no surface contamination has been identified up to this point. Contamination was captured as part of the air sampling using Millipore filters so these filters were also chosen to try for smears.

- All investigative air sampling will be performed a minimum of 1.5 hours. (Review of raw CAM spectral data ${ }^{12}$ from the event timeframe indicated that the releases lasted for less than an hour and a half before the room ventilation fully cleared the airborne radioactivity.)

The AFCI enclosure remained posted as an ARA during the testing period with workers wearing respiratory protection. The fixed CAM (located above the west door) and a job-specific CAM and air sampler (located near the west end of the AFCI glovebox) as required by the RWP were in service. "Lapel" air monitoring was utilized on workers performing tests. In some cases, as noted in the test descriptions below, investigative portable CAMs and air samplers were positioned in areas of interest. All CAMs were upgraded to version V.2.2.0.2 software and were set for Pu-239, Am-241, and U-235 isotopes of interest. (Refer to Section 6 for additional information on CAM software.) 


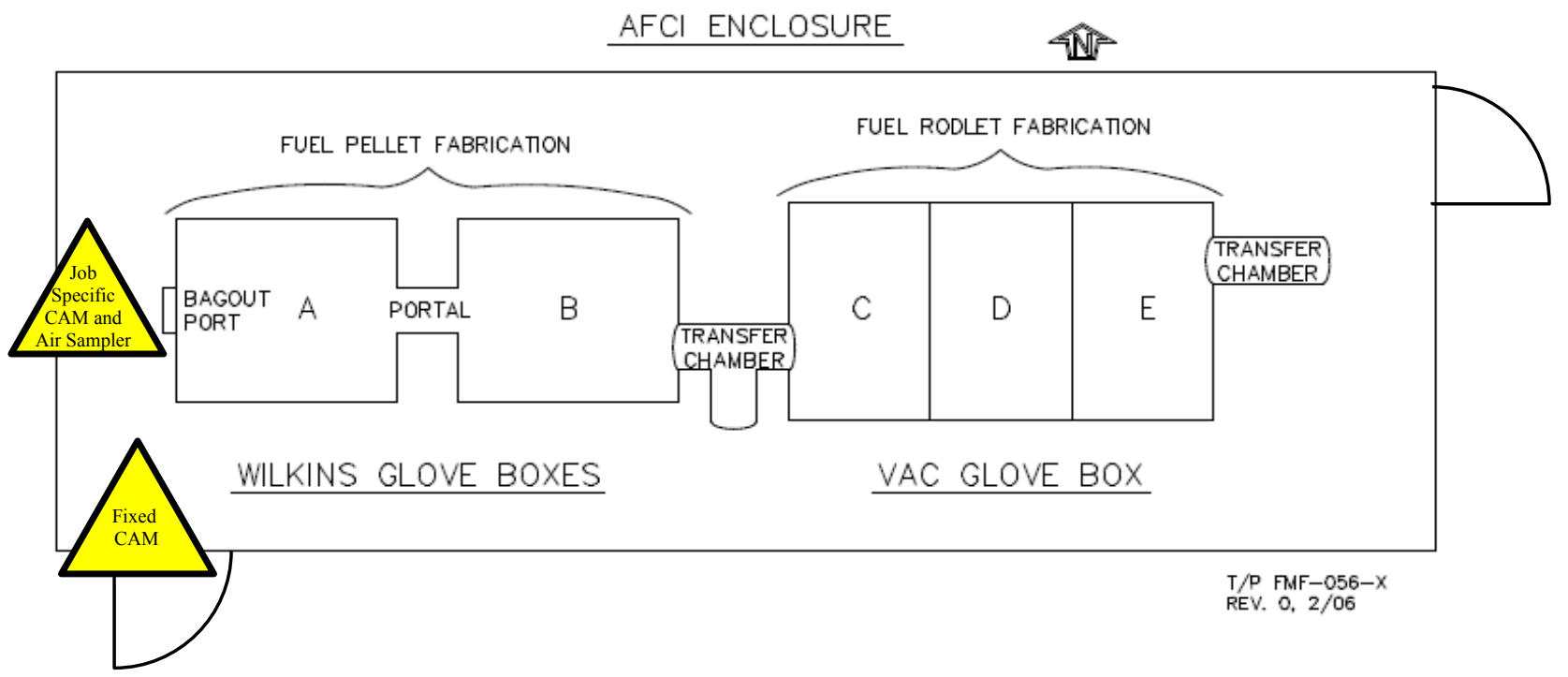

Figure 8. AFCI Enclosure and Fixed CAM and Job Specific CAM/Air Sampler Locations.

Radiological surveys were documented on radiological survey reports in accordance with MCP-139 ${ }^{13}$ and LRD-15001 ${ }^{14}$. Per LRD-15001 for the isotopes of concern in FMF, a surface is considered contaminated if either the removable or the total surface contamination exceeds the values listed in Table 2-2. Values less than the Table 2-2 limits are recorded as such on the survey reports (i.e., removable contamination as $<1000 \mathrm{dpm} / 100 \mathrm{~cm}^{2}$ for beta/gamma and $<20 \mathrm{dpm} / 100 \mathrm{~cm}^{2}$ for alpha, total [removable + fixed] as $<5000$ $\mathrm{dpm} / 100 \mathrm{~cm}^{2}$ beta gamma and $<100 \mathrm{dpm} / 100 \mathrm{~cm}^{2}$ alpha).

Radiological air monitoring results were documented on airborne survey results forms or radiological control evaluation forms in accordance with MCP-352 ${ }^{15}$ and LI-598 ${ }^{16}$. Fixed and job-specific CAMs/air samplers and lapel samplers were required by the RWP for personnel protection but the air sample data was also used to identify potential glovebox confinement breaches. Investigative CAMs/air samplers were used solely to identify potential glovebox confinement breaches.

Air filter data in this report is provided in "delayed count" disintegrations per minute (dpm) alpha and/or beta. Results less than the Minimum Detectable Activity (MDA) ${ }^{\mathrm{c}}$ for the given scaler and background conditions are reported as "less than MDA." Air samples were counted for ten minutes which generally provides a low MDA. For example, MDAs are generally less than $10 \mathrm{dpm}$ alpha when backgrounds are less than $1 \mathrm{cpm}$ alpha. "Delayed counts" are performed after a period of time (typically at least 7 days) to allow radon/thoron isotopes to decay. Two types of counting instruments were used for the job-specific and investigative CAMs/air samplers - the Canberra iSolo and the Ludlum 3030.

- The Canberra iSolo uses a solid state detector that is capable of determining the energy of the particle being detected. The iSolo is equipped with a multi-channel analyzer that uses a proprietary algorithm to remove counts from radon/thoron progeny.

- The Ludlum 3030 uses a dual phosphor sandwich (phoswich) scintillator detector. The system does not discriminate the radon/thoron progeny.

c MDA is based on the random nature of radioactive decay and the counting system's capability. MDA is the smallest level of radioactivity in a sample that can be detected with a 5\% probability of erroneously detecting radioactivity, when in fact none was present (Type I error) and also, a 5\% probability of not detecting radioactivity, when in fact it is present (Type II error). This equates to a $95 \%$ confidence level. 
The instrument used is noted for each test.

Testing was initiated in December 2014 and completed in September 2015. The testing and results are discussed below and are tabulated in Appendix A.

\subsubsection{Smoke Test of AFCI Enclosure}

Description - Smoke generators were used to qualitatively determine the direction and speed that airborne contamination from a potential breech in the glovebox confinement would travel.

$\underline{\text { Results }}$ - Multiple tests were performed (with variations on the FASS system operation):

- East transfer port to fixed CAM - Smoke went up to the ceiling, down to the floor, swirled around the east door before heading west and reaching the fixed CAM in approximately 1 minute 30 seconds.

- Tee transfer port to fixed CAM - Smoke flowed east, swirled around the east door, lingered near the ceiling, before flowing west to the fixed CAM in approximately 1 minute 17 seconds to 1 minute 46 seconds.

- Furnace gas exhaust panel located under Wilkins compartment A - Majority of smoke flowed toward the ceiling with some toward the floor before flowing west to the fixed CAM in approximately 31 to 54 seconds.

- Welding lead feedthroughs for the arc melter - Smoke stayed high, traveled west along the top of glovebox to the fixed CAM in approximately 24 to 38 seconds.

- Wilkins glove port WA-2 $5^{\mathrm{d}}$ - Smoke stayed high, traveled west along top of glovebox to the fixed CAM in approximately 7 to 24 seconds.

- Wilkins glove area between WA-19 and WA-20 - Traveled to the fixed CAM in approximately 25 seconds.

Evaluation of the airflow information is contained in section 7.2.

\subsubsection{Oil Sample from Gas Exhaust System Vacuum Pump (V3-PMP-114)}

Description - A sample of vacuum pump oil was analyzed to look for the presence of radiological material passing from the arc melter or the americium distillation furnace, through the two 0.2 micron filters (one inside of the glovebox and one outside of the glovebox) on the exhaust line, and to the vacuum pump.

Results - During the oil sampling evolution, smears and LAWs on the vacuum pump found no surface contamination above LRD-15001 Table 2-2 limits. Delayed count air filter surveys using the iSolo were less than MDA. Gamma spectroscopy and liquid scintillation (gross alpha/beta) of the oil sample identified no contamination above instrument detection limits.

\subsubsection{Gamma-Ray Detection}

Description - Gamma-ray spectrometry equipment was used to try to pinpoint possible locations of americium or other material buildup that is unexpected.

$\underline{\text { Results }}$ - An Ortec DigiBase Model 2M2/2 was utilized to scan the inlet and outlet of the 0.2 micron filter (V3-FLTR-114) located external to the glovebox that provides exhaust for the arc melter and americium distillation furnace. Background counts were performed by the americium distillation furnace (at the glovebox window and 1 foot away) and at the north wall of the AFCI enclosure. When the

\footnotetext{
${ }^{\mathrm{d}}$ The glove in port WA-25 was changed (including tool transfer into the glovebox with change) during the event timeframe (August 26, 2014).

${ }^{\mathrm{e}}$ This is the position the operator uses for arc melting.
} 
collected gamma-ray spectra were analyzed, no Am-241 was identified above instrument detection limits in the filter that was scanned.

\subsubsection{Americium Distillation Furnace Exhaust Line Integrity Checks}

Description - A vacuum was drawn on the exhaust line from the americium distillation furnace, the line isolated using in-line valves, and the pressure in the line monitored over time in an attempt to identify leaks in the line. An investigative CAM and air sampler were placed over compartment A of the Wilkins glovebox near the exhaust line.

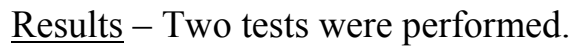

- Test \#1 - Line was isolated at 750 millitorr. In 3 minutes, pressure changed to 2000 millitorr and in 14 minutes pressure reached atmospheric. After the test, loose lock nuts were identified on some valves which should not have affected the test. The lock nuts hold gland nuts in place.

- Test \#2 - Gland nuts were checked for proper position and valves were manipulated to ensure proper seating. Line was isolated at 400 millitorr. In 6 minutes, pressure changed to 2000 millitorr and in 17 minutes pressure reached atmospheric.

During the testing, radiological monitoring identified no surface contamination above LRD-15001 Table 2-2 limits. Delayed count air filter surveys using the iSolo were less than MDA.

MFC Engineering reviewed the results in conjunction with the helium leak test results (see Section 5.2). The helium leak test revealed no leakage in the exhaust line. Engineering concluded the loss of vacuum in the exhaust line was due to losses through the valves, internal to the system, and not external leaks in the system. (MFC Engineering noted that leakage through the valves does not present a problem to system operation.)

\subsubsection{Arc Melter Exhaust Line Integrity Checks}

Description - A vacuum was drawn on the exhaust line from the arc melter, the line isolated using in-line valves, and the pressure in the line monitored over time in an attempt to identify leaks in the line. An investigative CAM and air sampler were placed over compartment A of the Wilkins glovebox near the exhaust line.

$\underline{\text { Results }}$ - One test was performed.

- Test - Line was isolated at 350 millitorr. In 9 minutes, pressure changed to 2000 millitorr and in 18 minutes pressure almost reached atmospheric.

During the testing, radiological monitoring identified no surface contamination above LRD-15001 Table 2-2 limits. Delayed count air filter surveys using the iSolo were less than MDA.

MFC Engineering reviewed the results in conjunction with the helium leak test results (see Section 5.2). The helium leak test revealed no leakage in the exhaust line. Engineering concluded the loss of vacuum in the exhaust line was due to losses through the valves, internal to the system, and not external leaks in the system. (MFC Engineering noted that leakage through the valves does not present a problem to system operation.)

\subsubsection{Secondary Pressure Control Component Checks}

Description - With the primary pressure control system of the Wilkins glovebox turned off, the secondary pressure control system was actuated by manipulating gloves. Checks were made for contamination from the secondary exhaust system piping and equipment. An investigative CAM and air sampler were placed over compartment A of the Wilkins glovebox near the exhaust line.

$\underline{\text { Results }}$ - The secondary pressure control system was actuated six times. Radiological surveys were performed including the Wilkins secondary exhaust pneumatic valve and filter housing and on the VAC secondary exhaust pneumatic valve. Smears were performed using Whatman 1 and Millipore filters. 
During the testing, radiological monitoring identified no surface contamination above LRD-15001 Table 2-2 limits. Delayed count air filter surveys using the iSolo were less than MDA.

\subsubsection{Purification Bed Exchange Checks}

Description - The purification beds (canisters) on the Wilkins glovebox purification system were switched from bed $\# 1$ to bed $\# 2$. Checks were made for contamination. An investigative CAM and air sampler were placed north of compartment A of the Wilkins glovebox near the purification system cabinet.

$\underline{\text { Results }}$-Smears were performed including the purification cabinet, body/housing/connections on the pneumatic valves on primary pressure control system, piping and blower of primary pressure control system.

During the testing, radiological monitoring identified no surface contamination above LRD-15001 Table 2-2 limits. Delayed count air filter surveys using the iSolo were less than MDA.

\subsubsection{Glove Replacement without Items Transferred In}

Description - A glove (WA-25) was changed out while checks were made for contamination including positioning of an investigative CAM intake approximately $2 \frac{1}{2}$ inches from the glove location. An investigative low volume air sampler was placed on top of the Wilkins glovebox above the gloveport.

$\underline{\text { Results }}$ - The used glove was examined and no issues were identified.

During the testing, radiological monitoring identified no surface contamination above LRD-15001 Table 2-2 limits. Delayed count air filter surveys using the iSolo were less than MDA.

\subsubsection{Internal Glove Inspections}

Description - Used gloves (pushed into the glovebox as part of the normal glove replacement process) were transferred out of the "tee" transfer port into the VAC glovebox for examination.

$\underline{\text { Results }}$ - Visible deformations (divots with little wrinkles) were seen on the gloves. "Stretch" testing was performed. No failures occurred and no holes were identified. Corresponding O-rings and Central Research Laboratories (CRL) support rings were visually examined with no signs of deformation.

\subsubsection{Glove Replacement with Items Transferred In}

Description - A glove (WA-25) was changed out while checks were made for contamination including positioning of an investigative CAM intake approximately $2 \frac{1}{2}$ inches from the glove location. An investigative low volume air sampler was placed on top of the Wilkins glovebox above the gloveport. Tooling was transferred into the glovebox as part of the change out.

$\underline{\text { Results }}$ - The used glove was examined and with some wrinkles and imperfections noted in the HPT log and no issues identified in the LI comments section.

During the testing, radiological monitoring identified no surface contamination above LRD-15001 Table 2-2 limits. Delayed count air filter surveys using the iSolo were less than MDA.

\subsubsection{Tee Transfer Port Operations}

Description - The "tee" transfer port was operated twice (2 different days) while checks were made for contamination including the south door and flange connection, exhaust connections, pressure gauge and connections, and the argon supply. An investigative CAM and air sampler were positioned by the transfer port. 
Results - A fixed CAM alarm (poor fit) was received during the second test. The CAM filter had just been changed out. The CAM read 0 DAC for Pu-239, Am-241, and U-235. The CAM alarm was determined to be spurious by Rad Con.

During the testing, radiological monitoring identified no surface contamination above LRD-15001 Table 2-2 limits. Delayed count air filter surveys using the iSolo were recorded up to $10.0 \mathrm{dpm}$ alpha and 33.0 dpm beta during the first test.

\subsubsection{Arc Melting Operations with Nonradiological Material}

Description -Arc melting operations were performed using nonradiological materials while surveys were for contamination including the argon supply line feedthrough, exhaust line feedthrough, and power supply feedthroughs. A cascade impactor (air monitoring equipment) was placed by the exhaust point of the AFCI enclosure.

Results -Three runs (each run consisting of two buttons and one cone, nine arc strikes total) were performed. Later in the day after the evolution, the HPT noticed a rise in the investigative CAM readout (resembling the Am-241 peak) but no alarms were received.

During the testing, radiological monitoring identified no surface contamination above LRD-15001 Table 2-2 limits. Delayed count air filter surveys using the iSolo were recorded up to $13.8 \mathrm{dpm}$ alpha and 12.0 dpm beta. $19.8 \mathrm{dpm}$ beta was also seen on the fixed CAM filter using a Tennelec counter. Counts from the plates on the cascade impactor showed no activity above background.

\subsubsection{Oxygen Analyzer Operations}

Description - The oxygen analyzers were manipulated (swapped, shut down, and restarted). Checks were made for contamination including the sample pumps, connections from analyzers to sample pumps, valves, eight way valve, and select internal components to the analyzers. An investigative CAM and air sampler were positioned near the oxygen analyzer cabinet.

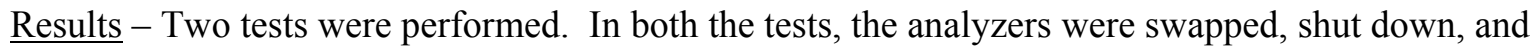
restarted.

Test \#1 - Activity was found on contamination smears of the oxygen analyzer and the job specific CAM alarmed (poor fit) at the completion of the test. Radiological monitoring identified $43 \mathrm{dpm} / 100 \mathrm{~cm}^{2}$ alpha on an oxygen analyzer (AHe-AE-034). During the testing, radiological monitoring identified no surface contamination above LRD-15001 Table 2-2 limits. Delayed count air filter surveys using the iSolo were recorded up to $56.0 \mathrm{dpm}$ alpha and $16.4 \mathrm{dpm}$ beta.

Test \#2 - The oxygen analyzer (AHe-AE-034) electrolyte fluid was sampled. Gamma spectroscopy identified no isotopes above detection limits and liquid scintillation counting identified $4.4 \mathrm{E}+1 \mathrm{dpm} / \mathrm{ml}$ of gross beta with no gross alpha contamination above detection limits. During the testing, radiological monitoring identified no surface contamination above LRD-15001 Table 2-2 limits. Delayed count air filter surveys using the iSolo were less than MDA.

\subsubsection{Arc Melting Operations using Nuclear Material}

Three tests using the arc melter were performed using transuranic material as noted below.

Test \#1 (May 21, 2015)

Description - The oxygen monitoring system and purification system was lined up in the same configuration as during the event (oxygen analyzer AHe-AE-034 in use and exhausting to suspect exhaust, purification bed \#2 on line). The following runs were performed:

- Run \#1 Pu-239, Zirconium (Zr) based fuel (Button \#1, Button \#2, Cone)

- Run \#2 Pu-239, Zr based fuel (Button \#1, Button \#2, Cone)

- Run \#3 Am-241, Zr based fuel (Button \#1) 
An investigative CAM was positioned to sample above the arc melter in compartment $A$ and an investigative air sampler was positioned on the north side of compartment A. In addition, all penetrations for compartment A were sealed off with bags. The bags containing the welding lead feedthroughs for the arc melter were outfitted with air filters connected to additional investigative air samplers.

$\underline{\text { Results }}$ - During the first and second runs, the three CAMs (fixed, portable, investigative) slowly and steadily climbed to 4.5 DAC, then leveled out on the Am-241 channel. During the third run the investigative CAM alarmed. The CAMs exhibited a rapid rise and stabilized at $40 \mathrm{DAC}$. During the testing, radiological monitoring identified no surface contamination above LRD-15001 Table 2-2 limits. Delayed count air filter surveys using the iSolo were recorded up to $4021.4 \mathrm{dpm}$ alpha and $165.8 \mathrm{dpm}$ beta.

During the glovebox component testing, air sampling around the welding lead feedthroughs identified potential leaks. Delayed count air filter surveys using the iSolo for the bagged welding lead feedthroughs were recorded up to $1472.3 \mathrm{dpm}$ alpha and $65.2 \mathrm{dpm}$ beta.

\section{$\underline{\text { Repairs }}$}

After Test \#1, the two welding lead feedthroughs were replaced. (They were installed several years prior.) At the same time, a thermocouple feedthrough for the americium distillation furnace was also replaced for other reasons.

Following Test \#1 and the feedthrough replacements, helium leak testing on the AFCI glovebox systems was performed and additional repairs made as noted in section 5.2.
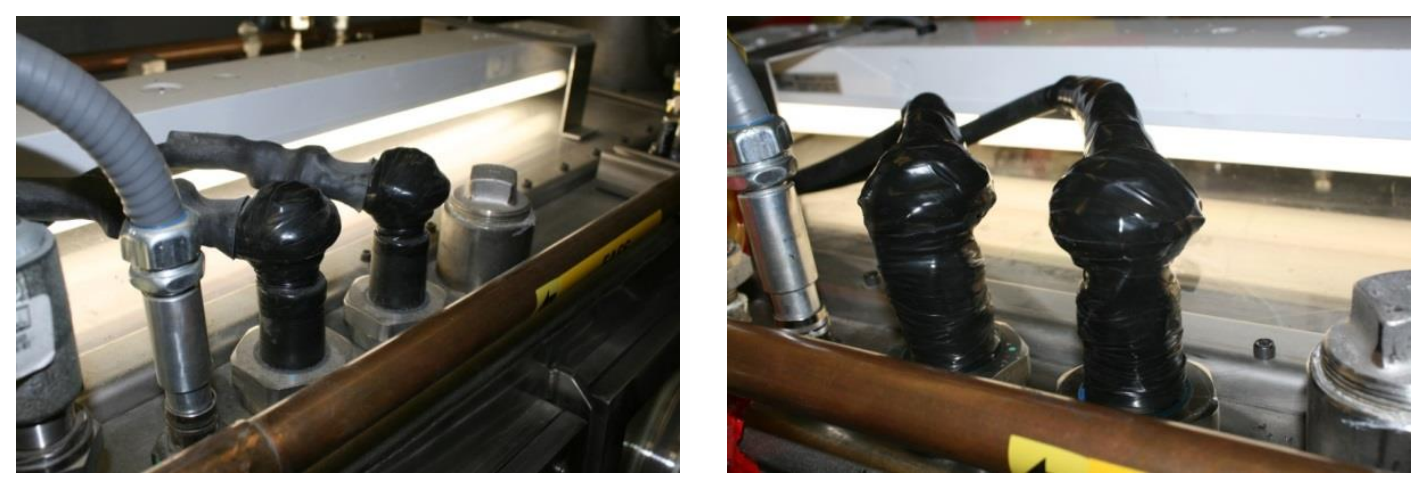

Figure 9. Welding Lead Feedthroughs for Arc Melter (Top of Compartment A).

Test \#2 (August 26, 2015)

Description - The oxygen monitoring system and purification system was lined up in the same configuration as during the event. The following runs were performed:

- $\quad$ Run \#1-Zr (using new welding leads)

- Run \#2 - Am-241, Zr based fuel

- Run \#3 - Am-241, Zr based fuel

An investigative CAM was positioned to sample above the arc melter in compartment $A$ and an air samplers were positioned at the "tee" transfer chamber and the HEPA filter housing to the enclosure exhaust (southwest corner).

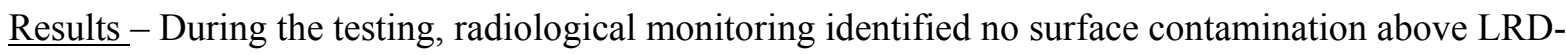
15001 Table 2-2 limits. Delayed count air filter surveys using the Ludlum 3030 were less than MDA.

Note - Decontamination activities were performed in the AFCI glovebox between test \#2 and \#3.

Test \#3 (September 2, 2015) 
Description - The lineup of the oxygen monitoring system and purification system was changed between runs. The following runs were performed:

- $\quad$ Run \#1 - Am-241, Pu-239, Zr based fuel (line up in same configuration as during event purification bed \#2 and sample from oxygen analyzer going to suspect exhaust)

- Run \#2 - Am-241, Pu-239, Zr based fuel (purification bed \#1 and sample from oxygen analyzer going to suspect exhaust)

- $\quad$ Run \#3 - Am-241, Pu-239, Zr based fuel (purification bed \#1 and sample from oxygen analyzer returning to glovebox)

- $\quad$ Run \#4 - Am-241, Pu-239, Zr based fuel (purification bed \#2 and sample from oxygen analyzer returning to glovebox)

An investigative CAM was positioned to sample above the arc melter in compartment $\mathrm{A}$ and air samplers were positioned at the "tee" transfer port and the HEPA filter housing to the enclosure exhaust (southwest corner).

Results - During the testing, radiological monitoring identified no surface contamination above LRD15001 Table 2-2 limits. Delayed count air filter surveys using the Ludlum 3030 were less than MDA.

\subsection{Glovebox Helium Leak Testing}

Helium leak testing of the AFCI glovebox (Wilkins portion) was pursued in an effort to obtain more definitive data on leak locations. Helium leak testing is normally accomplished by positively pressurizing a (clean) glovebox but the potential for contamination release from the AFCI glovebox precluded this as an option. Instead the testing was accomplished by shutting down the primary and secondary pressure controls and manually and maintaining a slight negative pressure in the glovebox during leak testing. A helium source was then attached to a glovebox injection port and helium introduced into the glovebox. Leak testing was performed in accordance with TPR-13438 ${ }^{17}$ with a minimum leak rate detection of $1.0 \mathrm{x}$ $10^{-5}$ standard cc/sec. The AFCI enclosure remained posted as an ARA during the testing period with workers wearing respiratory protection. The fixed CAM (located above the west door) and a job-specific CAM and air sampler as required by the RWP (located near the west end of the AFCI glovebox) were in service. "Lapel" air monitoring was utilized on workers.

On July 28, 2015 after arc melting test \#1 (see section 5.1.14) and the welding feedthrough replacements, the Wilkins glovebox atmosphere was changed to a slightly negative condition (just less than 0 in. $\mathrm{H}_{2} \mathrm{O}$ ), helium introduced, and four leaks were identified as noted in Table 2 below. No leaks were detected at the replaced feedthroughs, the americium distillation furnace exhaust line, or the arc melter exhaust line. During this test helium was detected around the HEPA filter housing for the glovebox suspect exhaust header. However it was later determined that this was not a leak; rather helium was permeating through the gasket over time. Based on discussions with MFC Engineering, this is a common occurrence with HEPA gaskets exposed to helium for an extended period and not an indication of equipment failure. Normal glovebox atmosphere was restored and repairs were made to the identified leak locations on August 11, 2015.

A second leak test was performed on August 17, 2015. Two addition leaks were detected as noted in Table 2 below. Normal glovebox atmosphere was restored and repairs were made on August 17 and 24.

A third leak test of the AFCI glovebox (oxygen analyzer, sample pump piping, feedthroughs, and HEPA filter housing) was performed on August 24, 2015 with no further leaks detected. Prior to the test, a smear on the eight way valve showed $43 \mathrm{dpm} / 100 \mathrm{~cm}^{2}$ and was decontaminated to less than LRD-15001 Table 2-2 limits.

The identified leaks and actions taken are summarized in Table 2 below and photographs of the components are contained in Appendix B. 
Table 2. Glovebox System Leaks Identified by Helium Leak Testing.

\begin{tabular}{|c|c|c|c|}
\hline Component with Leak & $\begin{array}{l}\text { Date Leak } \\
\text { Identified }\end{array}$ & $\begin{array}{l}\text { Description of Repair or } \\
\text { Replacement }\end{array}$ & $\begin{array}{c}\text { Date } \\
\text { Successfully } \\
\text { Helium Leak } \\
\text { Tested }\end{array}$ \\
\hline \multicolumn{4}{|c|}{ Oxygen Analyzers (Integrated Gas Analyzer System) } \\
\hline $\begin{array}{l}\text { Bellows pump (AHe-PMP-055) } \\
\text { for oxygen analyzer (AHe-AE- } \\
\text { 034) }\end{array}$ & $7 / 28 / 2015$ & $\begin{array}{l}\text { Bellow pumps (AHe-PMP-055 } \\
\text { and AHe-PMP-027) for both } \\
\text { oxygen analyzers were replaced }\end{array}$ & $\begin{array}{l}8 / 17 / 2015 \& \\
8 / 24 / 2015\end{array}$ \\
\hline $\begin{array}{l}\text { KF flange on exhaust line for } \\
\text { bellow pump (AHe-PMP-055) }\end{array}$ & $7 / 28 / 2015$ & $\begin{array}{l}\text { O-rings were replaced on the KF } \\
\text { flange. }\end{array}$ & $\begin{array}{l}8 / 17 / 2015 \& \\
8 / 24 / 2015\end{array}$ \\
\hline $\begin{array}{l}\text { Lower intake fitting on the oxygen } \\
\text { analyzer (AHe-AE-034) cabinet }\end{array}$ & $7 / 28 / 2015$ & Fitting was tightened. & $\begin{array}{l}8 / 17 / 2015 \& \\
8 / 24 / 2015\end{array}$ \\
\hline $\begin{array}{l}\text { Fitting on exhaust line on oxygen } \\
\text { analyzer (AHe-AE- } 034 \text { ) }\end{array}$ & $8 / 17 / 2015$ & Fitting was tightened. & $8 / 24 / 2015$ \\
\hline $\begin{array}{l}\text { Fitting on eight way valve (AHe- } \\
\text { MV-001) }\end{array}$ & $8 / 17 / 2015$ & Fitting was repaired/tightened. & $8 / 24 / 2015$ \\
\hline \multicolumn{4}{|l|}{ Primary Pressure Control System } \\
\hline $\begin{array}{l}\text { Filter housing in pressure control } \\
\text { cabinet }\end{array}$ & $7 / 28 / 2015$ & Bolts were tightened. & $\begin{array}{l}8 / 17 / 2015 \& \\
8 / 24 / 2015\end{array}$ \\
\hline \multicolumn{4}{|l|}{ Arc Melting System } \\
\hline Welding lead feedthroughs & $\begin{array}{l}5 / 21 / 2015 \\
\text { (identified } \\
\text { from arc melt } \\
\text { test \#1) }\end{array}$ & Feedthroughs were replaced & $7 / 28 / 2015$ \\
\hline
\end{tabular}

In addition, all the 0.2 micron filters on the AFCI glovebox system were replaced.

Arc melting tests \#2 and \#3 (see section 5.1.14) were performed subsequent to the repairs and final helium leak test.

\subsection{Glovebox Research Operations after Leak Repairs}

A series of five arc melting operations were performed to confirm that the glovebox confinement was repaired and satisfactory confinement results could be replicated during arc melting operations. The research operations were performed using the normal operating procedure FMF-OI-607, "AFCI Glovebox Equipment Operations," 18 (and not the test procedure used earlier). The oxygen analyzer system was lined up to flow through oxygen analyzer AHe-AE-034 (previously found to be leaking). 
The AFCI enclosure remained posted as an ARA during the arc melting runs with workers wearing respiratory protection. The fixed CAM (located above the west door) and a job-specific CAM and air sampler as required by the RWP (located near the west end of the AFCI glovebox) were in service. "Lapel" air monitoring was utilized on workers performing tests. Investigative portable CAMs and air samplers were also utilized.

The following research operations were performed:

- Research Operation \#1 (November 2, 2015) - Depleted uranium (Du), Zr based fuel

- Research Operation \#2 (November 3, 2015) - Pu-239, Zr based fuel

- Research Operation \#3 (November 4, 2015) - Du, Zr based fuel

- Research Operation \#4 (November 5, 2015) - Du, Zr based fuel

- Research Operation \#5 (November 10, 2015) - Du, Zr based fuel and Pu-239, Am-241, Zr based fuel

The "tee" transfer port was operating several time during the operations to support the material arc melting activities. Tools and material were transferred.

During the operations, radiological monitoring identified no surface contamination above LRD-15001 Table 2-2 limits. Delayed count air filter surveys using the Ludlum 3030 were recorded for each of the five arc melting operations with all results less than MDA. The results are tabulated in Appendix A.

\subsection{Evaluation of Glovebox Performance and Corrective Actions}

During glovebox component testing, the activities noted below had airborne activity detected which indicated glovebox confinement breaches.

- $\quad$ Tee Transfer Port Operations - Delayed count air filter surveys up to $10.0 \mathrm{dpm}$ alpha and 33.0 dpm beta. It should be noted that the air sampling near the tee transfer port is also near the bellows pumps for the oxygen analyzers. It is suspected that the contamination came from the oxygen analyzer system due to its proximity to the tee transfer port.

- Oxygen Analyzer Operations - Surface contamination up to $43 \mathrm{dpm} / 100 \mathrm{~cm}^{2}$ alpha on the oxygen analyzer, $4.4 \mathrm{E}+1 \mathrm{dpm} / \mathrm{ml}$ of gross beta contamination in the electrolyte sample, CAM alarm, and delayed count air filter surveys up to $56.0 \mathrm{dpm}$ alpha and $26.0 \mathrm{dpm}$ beta.

- $\quad$ Arc Melting Operations (Nonradiological Materials) - Delayed count air filter surveys up to 13.8 dpm alpha and $19.8 \mathrm{dpm}$ beta.

- $\quad$ Arc Melting Operations using Nuclear Materials (Test \#1) - CAM alarm and delayed count air filter surveys up to $4021.4 \mathrm{dpm}$ alpha and $165.8 \mathrm{dpm}$ beta.

The glovebox component testing indicated confinement breaches in the oxygen analyzer system and possibly the tee transfer port. Testing also indicated creation of a volatile form of Am-241 during arc melting operations that was able to escape the glovebox confinement system. (See Section 7.3 for additional information.) This is further supported by occurrence of CAM alarms after arc melting runs during the event timeframe of August 26 to August 28, 2014 (see section 6.4 for discussion). However, it should be noted that the negative results (no contamination detected) for the remainder of the glovebox component testing did not fully rule out breaches in those areas. Without handling/processing of transuranic materials during much of the testing, the airborne contamination conditions within the 
glovebox may have been different. This led to the decision to perform helium leak testing to better pinpoint the confinement breaches. Based on the results of both the glovebox component testing and the helium leak testing, the following equipment was identified as potential leak paths to the glovebox confinement:

- Welding Lead Feedthroughs - Air sampling of the bagged welding lead feedthroughs identified contamination during arc melting

- $\quad$ Oxygen Analyzer System - Helium leak testing identified several components

- $\quad$ Primary Pressure Control Filter Housing - Helium leak testing identified a fitting

The oxygen analyzer system appears to be the main source of leaks based on the results of both the glovebox component testing and the helium leak testing. The path for the gas sample is from the glovebox through a filter located inside the glovebox, eight-way valve, sample pump, oxygen analyzer, eight-way valve, and either through a filter located outside the glovebox leading back into the glovebox or to suspect exhaust. In the AFCI glovebox design description", it was noted that "there are filters at the boundary of the gloveboxes to limit the migration of powders out of the glovebox." It is suspected that a portion of volatized Am-241 from the arc melting process was released into the glovebox and passed through the filter into the gas analyzer system. This could be due to either a failed 0.2 micron filter or due to the ability of the volatized Am-241 to permeate the filter. This is discussed further in section 7.3.

The immediate corrective actions were to replace the welding lead feedthroughs, repair or replace leaking oxygen analyzer system components, tighten the fitting on the primary pressure control filter housing, and replace all 0.2 micron filters. After the repairs, helium leak testing of the AFCI glovebox (including associated systems) indicated no leaks in excess of $1.0 \times 10^{-5}$ standard $\mathrm{cc} / \mathrm{sec}$.

After the repairs, arc melting tests \#2 and \#3 (including Am-241) were performed under LI-692. During the testing, radiological surveys identified no surface contamination above LRD-15001 Table 2-2 limits. Delayed count air filter surveys using the Ludlum 3030 were less than MDA. This concluded the glovebox component testing.

Program work resumed in the AFCI glovebox with five separate arc melting operations and operation of the "tee" transfer port. The AFCI enclosure conservatively remained posted as an ARA with the workers using respiratory protection. During the five research runs and the associated "tee" transfer port operations, radiological surveys identified no surface contamination above LRD-15001 Table 2-2 limits. Delayed count air filter surveys were all less than MDA.

Based on the results above, the AFCI glovebox confinement boundary has been repaired. The air sampling results from the five research operations were evaluated in RCE-FMF-2015-17 ${ }^{19}$ which concluded that air samples were all less than 2 effective DAC-hrs, therefore no DAC-hour tracking or further evaluation was needed. Under these conditions, the ARA posting for the AFCI enclosure is no longer required and can be removed.

The following interim corrective actions to mitigate reoccurrence of AFCI glovebox confinement breaches were implemented:

- A Preventive Maintenance Justification (PMJ) has been established identifying the need for annual helium leak testing of the AFCI glovebox confinement boundary and associated subsystems every six months. 
- A PMJ has been established identifying the need to replace the bellows pumps on the oxygen analyzer system every three years. The metal bellows are known to experience fatigue over time.

- A PMJ has been established identifying the need to replace the 0.2 micron filters on the AFCI glovebox systems annually.

Labway issue CO 2015-4536 has been established for MFC Engineering to evaluate the potential for similar confinement vulnerabilities with other BEA glovebox systems and develop corrective actions as appropriate. The AFCI glovebox interim corrective actions above will then be modified or supplemented if needed based on the evaluation results. 


\section{Radiation Monitoring Description}

\subsection{Continuous Air Monitors (CAMs)}

The AFCI enclosure is typically monitored by two Alpha 7A CAMs manufactured by Thermo Eberline. One CAM is stationary and located near the room suspect exhaust ventilation. One CAM is a portable system located near the work activities. A CAM was required at the time of the event in the AFCI enclosure per ECAR- $897^{20}$ based on the potential intake fraction from AFCI glovebox activities.

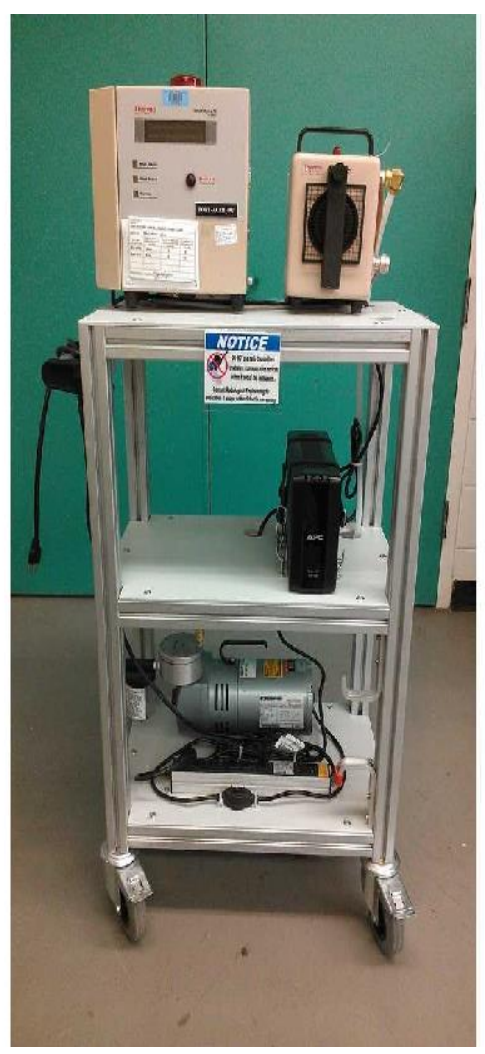

Figure 10. Example of Alpha 7A CAM.

The Alpha 7A CAM relies on peak fitting and peak shaping to identify and quantify isotopes of interest. The CAM utilizes peak shape analysis to identify (subtract) interference from naturally occurring isotopes (radon and thoron progeny) thereby determining the activity for specific isotopes of interest. This method also allows for automatic gain adjustment to constantly insure that the reference peaks are aligned with the proper energy. The curve fitting is performed using a proprietary peak shape mode and iterative algorithm developed by Thermo Eberline specifically for the Alpha 7. The CAM periodically evaluates the curve fit to the actual spectrum counts, using a goodness-of-fit indicator. If a bad fit is obtained for 20 consecutive measurements, then a poor fit status is indicated and the CAM enters a failed condition.

Prior to the event, the CAMs were operating using V.1.9.1.2 software. MFC was in the process of upgrading the existing Alpha 7A CAMs to V.2.2.0.2 software that has a better radon and thoron progeny compensation algorithm as part of an effort to reduce the false alarm rate. The upgrade process involved installation of an upgrade kit from the manufacturer including computers and internal components. The AFCI enclosure fixed CAM was upgraded on the morning of August $27^{\text {th }}$. The portable CAM was not upgraded during that week. 
The older V.1.9.1.2 Alpha 7A CAMs have had difficulty processing more than two isotopes of interest in addition to the radon and thoron progeny. Therefore, only Pu-239 and U-235 were selected as isotopes of interest for monitoring prior to the software upgrade and was not changed with the upgrade. $\mathrm{Pu}-239$ is a predominant radionuclide in the majority of facilities monitored by Alpha 7A CAMs. Pu-239 was expected to be present if a release including Am-241 were to occur. In addition, $\mathrm{Pu}-239$ emits a 5.15 $\mathrm{MeV}$ alpha particle, which appears on the low energy tail of the Am-241 peak at 5.5 MeV. Therefore, a release that included $\mathrm{Am}-241$ was expected to be identified by the $\mathrm{CAM}$ as $\mathrm{Pu}-239$ and result in an alarm if $\mathrm{Pu}-239$ was selected as the dose isotope.

The CAMs were set to alarm at a slow concentration of 8 DAC using a 1 hour evaluation window and a fast concentration of $500 \mathrm{DAC}$ using a 5 minute evaluation window. The fast concentration alarm is used to give rapid alarm response on high (acute) concentrations. The slow is used to accurately measure lower (chronic) concentrations. The CAM has the capability of being set to alarm using a dose alarm (e.g., 8 DAC-hr). Dose alarms are beneficial for low level chronic releases that are below the fast/slow concentration setpoints. The dose alarm was not used in this facility since releases were expected to be of an acute nature if they were to occur.

During the event timeframe, the RWP did not require a job-specific CAM or job-specific air sampler.

\subsection{Fixed Air Sampling System (FASS)}

The FASS utilizes a venturi pump system to sample air from various locations within FMF. Sample air is drawn through glass fiber filters that are periodically removed and analyzed.

The FASS was out of service at the time of the event due to a pump upgrade, so a low volume air sampler was used to monitor the work location in lieu of the FASS.

\subsection{Air Sample Filter Analysis}

Air filters from CAMs, FASS, and air samplers may have initial and retrospective analysis (radon/thoron decayed count referred to herein as "delayed") performed in accordance with MCP-352 ${ }^{15}$ and LI-598 ${ }^{16}$. This ensures that any activity levels which may be below CAM alarm thresholds are identified. Additionally, retrospective filter analysis provides additional confirmation that the CAM is configured correctly for field monitoring.

Per LI-598 (Rev. 1 in effect at the time of the event), air filters from job specific air samplers are initially counted after the job (counts are automatically compensated for radon/thoron progeny and background when using Canberra iSolo counters) and Derived Air Concentration (DAC) is calculated. Total DAC fraction greater than 0.3 DAC requires the area to be posted as an Airborne Radioactivity Area (ARA).

Per MCP-352 (Rev. 8 in effect at the time), air filters from routine monitoring (e.g., CAM or FASS) have a "delayed" count and DAC is calculated. Total DAC fraction greater than 0.02 DAC requires Radiological Controls management review to determine if bioassay is required. Routine air sample results are reviewed and trended quarterly.

On September 24, 2014, during review of results for routine delayed counting of air sample filters, transuranic material was discovered on air sample filters collected from the FMF AFCI enclosure during the period from August 26 through August 28, 2014. Two of the air sample filters in question were from the AFCI enclosure fixed continuous air monitor (CAM) and two were from the portable low volume air sampler (used in lieu of the FASS).

\subsection{Airborne Release Timeline}

The Alpha 7A CAM stores a significant amount of historical data. A review and reconstruction of raw CAM spectral data during the event timeline identified a broad peak very closely approximating Am-241 in several instances. The airborne radioactivity releases were reconstructed from available data and documented in INL/INT-14-00118 ${ }^{12}$. Information from the report is summarized below. 
Table 3. Approximate Airborne Radioactivity Release Periods and CAM Alarm Status

\begin{tabular}{|c|c|c|c|c|}
\hline Date & $\begin{array}{l}\text { Glovebox } \\
\text { Activities }\end{array}$ & $\begin{array}{l}\text { Approximate } \\
\text { Airborne } \\
\text { Radioactivity } \\
\text { Release Period }\end{array}$ & Alarms & Response $^{\mathrm{g}}$ \\
\hline \multirow[t]{2}{*}{$8 / 26 / 14$} & $\begin{array}{l}\text { Changed glove } \\
\text { and inserted tools, } \\
\text { commenced arc } \\
\text { melting - } \sim 08: 00^{\mathrm{h}}\end{array}$ & \multirow[t]{2}{*}{$10: 30$ to $12: 00$} & $\begin{array}{l}\text { Fixed CAM } \\
12: 23 \text { to } 12: 41 \\
\text { Slow } \\
\text { concentration }\end{array}$ & $\begin{array}{l}\text { Fixed CAM - Facility was } \\
\text { unoccupied at the time of the } \\
\text { alarm. Checked the next } \\
\text { morning }(8 / 27) \text {. No signs of } \\
\text { release on remote readout for } \\
\text { fixed CAM. No increase in } \\
\text { background count rate on hand } \\
\text { monitors in enclosure. No surface } \\
\text { contamination found above LRD- } \\
15001 \text { Table } 2-2 \text { limits. CAM } \\
\text { filter changed. }\end{array}$ \\
\hline & $\begin{array}{l}\text { Placed glovebox } \\
\text { in standby mode - } \\
12: 06\end{array}$ & & $\begin{array}{l}\text { Portable CAM } \\
\begin{array}{l}13: 34 \text { to } 07: 46 \\
\text { (on } 8 / 27 / 14 \text { ) } \\
\text { Poor fit }\end{array}\end{array}$ & $\begin{array}{l}\text { Portable CAM - Facility was } \\
\text { unoccupied at the time of the } \\
\text { alarm. Checked the next morning } \\
(8 / 27) \text {. No activity on remote } \\
\text { readout for fixed CAM. No } \\
\text { increase in background count rate } \\
\text { on hand monitors in enclosure. } \\
\text { No surface contamination found } \\
\text { above LRD-15001 Table } 2-2 \\
\text { limits. CAM filter changed. }\end{array}$ \\
\hline \multirow[t]{4}{*}{$8 / 27 / 14$} & \multirow{2}{*}{$\begin{array}{l}\text { Completed } \\
\text { replacement of } \\
\text { gauge on transfer } \\
\text { port }-09: 10\end{array}$} & $10: 20$ to $11: 20$ & \multirow{4}{*}{$\begin{array}{l}\text { Portable CAM } \\
\text { 13:56 to 14:17 } \\
\text { (log stopped) } \\
\text { Poor fit }\end{array}$} & \multirow{4}{*}{$\begin{array}{l}\text { AFCI Enclosure evacuated. No } \\
\text { surface contamination found } \\
\text { above LRD-15001 Table 2-2 } \\
\text { limits. CAM filter changed. } \\
\text { CAM placed out of service. }\end{array}$} \\
\hline & & \multirow{3}{*}{$\begin{array}{l}\text { Potential } 14: 15 \\
\quad \text { to } 14: 45 \\
\text { Potential } 16: 30 \\
\quad \text { to } 17: 30\end{array}$} & & \\
\hline & $\begin{array}{l}\text { Started arc melting } \\
-10: 05^{\mathrm{h}}\end{array}$ & & & \\
\hline & $\begin{array}{l}\text { Placed glovebox } \\
\text { in standby mode - } \\
11: 30\end{array}$ & & & \\
\hline \multirow[t]{3}{*}{$8 / 28 / 14$} & $\begin{array}{l}\text { Started arc melting } \\
-\sim 08: 30^{\mathrm{h}}\end{array}$ & \multirow[t]{3}{*}{$14: 00$ to $15: 20$} & \multirow{3}{*}{$\begin{array}{l}\text { Fixed CAM } \\
\text { 16:47 to } 17: 48 \\
\text { (log stopped) } \\
\text { Poor fit }\end{array}$} & \multirow{3}{*}{$\begin{array}{l}\text { Facility was unoccupied at the } \\
\text { time of the alarm. CAM filter } \\
\text { changed on the next working day } \\
(9 / 2 / 14) \text {. }\end{array}$} \\
\hline & $\begin{array}{l}\text { Placed glovebox } \\
\text { in standby mode - } \\
11: 32\end{array}$ & & & \\
\hline & Started arc melting & & & \\
\hline
\end{tabular}

\footnotetext{
${ }^{\mathrm{f}}$ Taken from Critique Report.

g Taken from Rad Con and facility logs.

${ }^{\mathrm{h}}$ Arc melting was performed using mixtures of $\mathrm{Pu}, \mathrm{Np}, \mathrm{Am}$, and zirconium.
} 


\begin{tabular}{|c|c|c|c|c|}
\hline Date & $\begin{array}{l}\text { Glovebox } \\
\text { Activities }^{f}\end{array}$ & $\begin{array}{c}\text { Approximate } \\
\text { Airborne } \\
\text { Radioactivity } \\
\text { Release Period }\end{array}$ & Alarms & Response $^{\mathrm{g}}$ \\
\hline & $-\sim 13: 30^{\mathrm{h}}$ & & & \\
\hline & $\begin{array}{l}\text { Placed glovebox } \\
\text { in standby mode - } \\
\text { 15:06 }\end{array}$ & & & \\
\hline $9 / 3 / 14$ & & $\begin{array}{l}\text { Sometime prior } \\
\text { to } 00: 45\end{array}$ & $\begin{array}{c}\text { Fixed CAM } \\
\text { 01:47 to } 7: 54 \\
\text { Fast/slow } \\
\text { concentration }\end{array}$ & $\begin{array}{l}\text { Facility was unoccupied at the } \\
\text { time of the alarm. No surface } \\
\text { contamination found above LRD- } \\
15001 \text { Table } 2-2 \text { limits. Hand } \\
\text { held instruments showed no } \\
\text { unusual elevation in count rates. } \\
\text { CAM filter changed. CAM filter } \\
\text { was counted (after decay) and was } \\
\text { less than } 0.3 \text { DAC. }\end{array}$ \\
\hline
\end{tabular}

The airflow characteristics of the room provided for poor mixing and short clearance times. The room experiences approximately 5 air exchanges per hour and the direction of flow is generally straight from supply to exhaust. Based upon later analysis of data stored by the CAMs, releases during the event did not appear to be discrete (e.g., "puff' releases) but rather more of a continuous nature. Releases lasted for less than an hour and a half before the room ventilation fully cleared the airborne radioactivity.

Arc melting was performed on September 23 and the morning of September 24, 2014. (This was just prior to receiving results from the delayed count of air filters for August 25 to September 2, 2014 indicating airborne activity.) Delayed count of the air filter for the fixed CAM for the week of September 22 to 29, 2014 identified no airborne contamination (i.e., results were less than $1 \mathrm{dpm}$ alpha and beta). 


\section{Evaluation of Radiation Monitoring Performance and Corrective Actions}

\subsection{Alpha 7A CAM Evaluation}

Performance of the Alpha 7A CAMs was evaluated in INL/INT-14-00118 ${ }^{12}$ and summarized herein.

Am-241 was identified as the primary radionuclide present in the releases based on counting of CAM filters and bioassay results. This differed from the expectation of $\mathrm{Pu}-239$ as one of the constituents to a contamination release based on past operating experience.

The largest contributor to the poor CAM performance was the release characteristics being dominated by Am-241 and not having Am-241 selected as a isotope of interest (i.e., those quantified by the CAM which are used to trigger to alarm). This had the following effects on the overall performance.

- In some instances, Am-241 was treated as the radon progeny Po-218 (background) by the CAM algorithm. This was a non-conservative response. The algorithm "shifted" the curve fit causing the CAM to no longer function properly (illustrated in Figure11).

- In some instances, the "tail" of the Am-241 peak was treated as Pu-239 by the CAM algorithm and caused a concentration alarm after the suspected releases. This was the expected (conservative) response.

- In some instances, the CAM responded with a "poor fit" alarm after the suspected releases subsided.

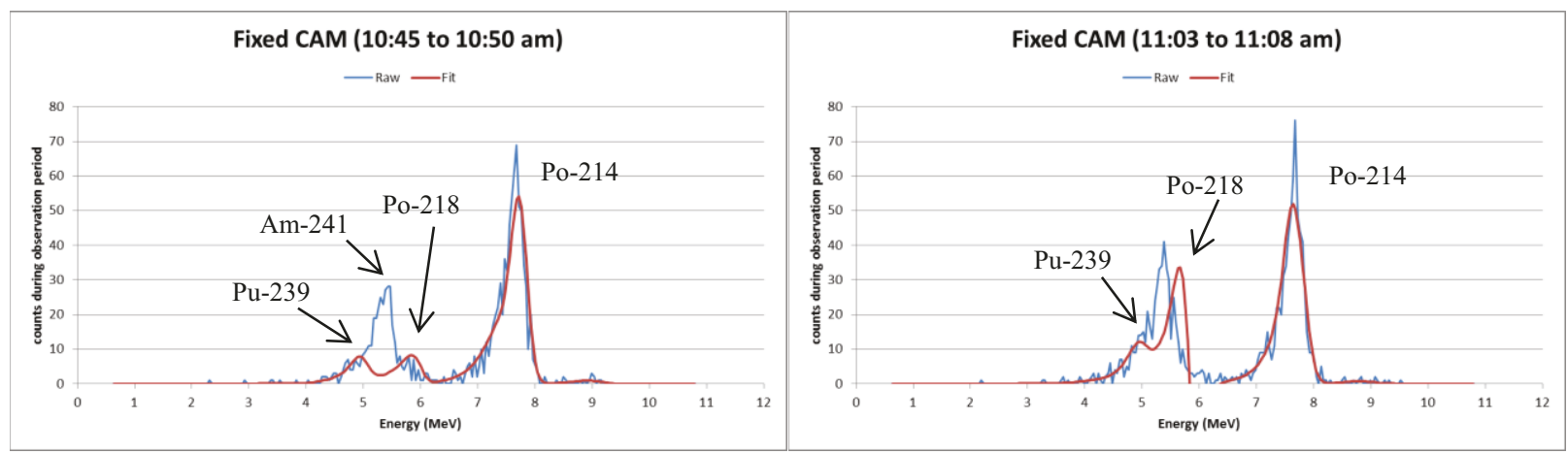

Figure 11. CAM algorithm shifting the Po-218 peak fit to Am-241 on 8-27-14.

Details about how the peak curve fitting algorithm occurs are proprietary so its limitations were unknown prior to the event. Had Am-241 been selected as an isotope of interest, the CAM would have alarmed sooner after the onset of the release, not resulted in poor fit conditions, and better quantified the magnitude of the release.

At the time of the events, operation and in-field troubleshooting for the Alpha 7A CAM was performed per TPR-7638 (Rev. 6) ${ }^{21}$. In the TPR, causes of poor fit were identified as environmental interference (e.g., RF signals, light leaks), radon/thoron progeny build-up, dirt on filter or detector, incorrect air filter installation, or damaged detector. Response to a "poor fit" and fast or slow concentration alarm are 
summarized in Table 4. The potential for a "poor fit" due to the detection of radionuclides that did not fit the prescribed spectra was not known at the time, so the TPR did not address it.

Table 4. Poor Fit and Slow Concentration Alarm Responses Summarized from TPR-7638, Rev. 6.

\begin{tabular}{|c|c|c|}
\hline Status Condition & Possible Causes & Possible Repairs \\
\hline \multirow[t]{12}{*}{ Poor Fit } & \multirow{3}{*}{$\begin{array}{l}\text { Noise in the spectrum }<3.0 \\
\text { MeV generated from } \\
\text { environmental interference } \\
\text { (e.g. RF signals, light leaks) }\end{array}$} & Relocate CAM head \\
\hline & & Replace the filter (this will clear the spectrum) \\
\hline & & $\begin{array}{l}\text { If problem does not clear, have } \mathrm{I} \& \mathrm{C} \text { or } \\
\text { Radiological Engineering evaluate }\end{array}$ \\
\hline & $\begin{array}{l}\text { A filter that has already } \\
\text { accumulated } \mathrm{Rn} / \mathrm{Th} \text { progeny } \\
\text { was placed into the CAM }\end{array}$ & Install a new filter \\
\hline & $\begin{array}{l}\text { Dirt on filter has caused a peak } \\
\text { shift in the spectrum }\end{array}$ & Install a new filter \\
\hline & \multirow[t]{3}{*}{$\begin{array}{l}\text { Dirt on the detector face has } \\
\text { caused peaks to appear }\end{array}$} & $\begin{array}{l}\text { Analyze the spectrum or looking for dirt on the } \\
\text { detector face }\end{array}$ \\
\hline & & Clean the detector \\
\hline & & Install a new filter \\
\hline & $\begin{array}{l}\text { Wrong side of air filter facing } \\
\text { detector }\end{array}$ & Install a new filter \\
\hline & $\begin{array}{l}\text { (This causes extreme spectrum } \\
\text { broadening and noise buildup) }\end{array}$ & \\
\hline & \multirow[t]{2}{*}{ Damaged detector } & Inspect detector face for signs of damage \\
\hline & & If damage is suspected, remove from service \\
\hline $\begin{array}{l}\text { Fast Concentration } \\
\text { or Slow } \\
\text { Concentration }\end{array}$ & $\begin{array}{l}\text { Software calculated dose } \\
\text { exceeds alarm threshold }\end{array}$ & Evacuate area and respond per LWP- $15015^{22}$ \\
\hline
\end{tabular}

Radiological Controls response to both alarm types at the time of the event included evaluating the fixed CAM remote readout and making an entry (with respiratory protection for concentration alarms only) to survey for surface contamination, check the alarm status of other radiological instrumentation (e.g., alpha hand monitors, other CAM), and obtain an air sample for counting. Responses by alarm event are summarized in Table 3.

A condition was entered into the INL issues management tracking system (Labway CO 2014-4927) and the following actions taken.

1. Update the software on all Alpha-7A CAMs to the most current version. This was completed for all in-service CAMs at MFC.

2. Evaluate adding the dose alarm settings to the Alpha-7A CAM to monitor for slow release of radioactive material for ALARA purposes. ECAR-127 $7^{23}$ was revised to include CAM dose alarm settings for MFC facilities/areas that require real time monitoring for normal and routine access. The same settings apply to other fixed and portable CAMs not specified in other documents. For 
the Alpha 7 CAMs, the alarms for the isotopes of interest are 500 DAC for fast concentration, 8 $D A C$ for slow concentration, and $8 D A C$-hr for dose.

3. Verify that CAMs are set for the proper radionuclides for the specific work. ECAR-127 ${ }^{23}$ was revised to include alpha CAM radionuclide settings for MFC facilities/areas that required realtime monitoring for normal and routine access. In-service CAM settings were adjusted accordingly. Job-specific CAM radionuclide settings will be determined by the ALARA review. Am-241 and Pu-239 were identified as the isotopes of interest for the CAMs in the FMF AFCI enclosure.

4. Evaluate the ability to modify the alarm channel to a transuranic region that more correctly represent the various radionuclides. TEV-2423 ${ }^{24}$ was issued and included the following discussion on the use of a transuranic region of interest:

"Do not use the region of interest configuration as described in the manual with version 2.2.0.2 as it is not functional in the software code. Thermo recommended using multiple isotopes to create a "pseudo region of interest" (one that could be set to monitor for many isotopes using bounding energies and the most conservative DAC reference values)."

5. Revise PDD-15001 to include technical basis for CAM alarm set points. PDD-15001, "Air Monitoring Technical Basis Document, "25 was revised to provide further discussion on CAM alarm set points. TEV-2423 also provides information on CAM set points for the Alpha $7 A$ CAMs.

6. Submit Lessons Learned. A lessons learned was submitted to OPEXShare and is discussed in section 8.2 of this report.

7. Evaluate permanently changing the response to trouble alarms on the Alpha-7A to ensure that potential real alarms are properly responded to and not missed. TPR-7638, "Thermo Alpha 7A CAM Operation and Performance Checks, ${ }^{, 26}$ has been revised to have an initial response to evacuate the area and respond per LWP-15015. The CAM "poor fit" alarm is treated as an airborne activity alarm until confirmatory counting of air filter(s) is complete.

8. Provide training to RadCon staff on poor fit alarms. Training was provided to HPTs and Radiological Controls supervisors on the changes to TPR-7638.

\subsection{Air Flow and Air Monitoring Locations Evaluation}

The FMF ventilation supply fan (SF-1) directly delivers air via ductwork to the AFCI enclosure. Additional supply air is indirectly (ductless) supplied from the north workroom to the AFCI enclosure. The FMF exhaust system pulls are from the AFCI enclosure through the room exhaust on the west side directly into the AFCI enclosure HEPA filters. The exhaust flow is also HEPA filtered prior to exiting the FMF through the exhaust stack.

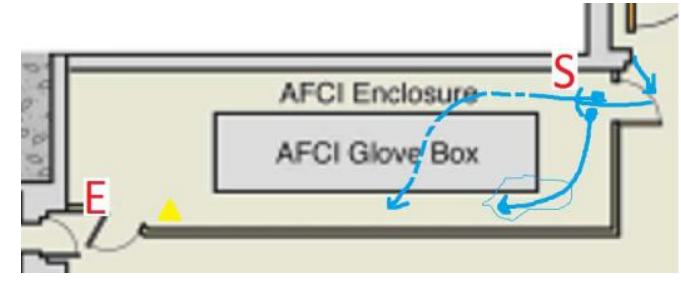

Figure 12. AFCI enclosure general area airflow patterns.

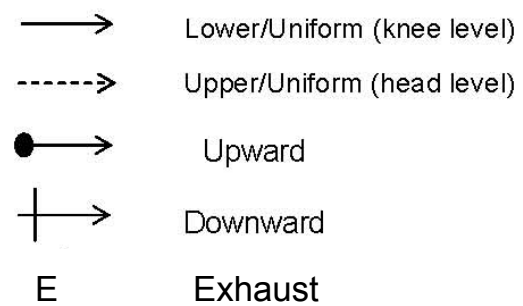

Supply 
Smoke testing was performed and documented in ECAR-2344. ${ }^{27}$ Smoke was released from the hallway towards the east personnel door (closed) at floor level. Smoke was observed entering the room through the grate in the door and along the bottom of the door, demonstrating that the room is negative to the North Workroom.

Personnel doors were closed during testing. Smoke was released immediately inside the door (closed) at floor level which allowed for rise to breathing zone level due to heat. Smoke was observed traveling towards the southwest corner of the room, wrapping around the glovebox. The southeast end of the glovebox was somewhat stagnant; however this area of the glovebox has less contamination potential since it is treated as the "clean" side of the glovebox. The supply damper near the east entrance was closed during the tests. Operations personnel indicated they keep it closed due to the excessive heat in the winter and open during the summer to help cool the room. The operator opened the damper and clear directional flow was experienced in a downward direction towards the west side of the room. The smoke velocity was approximately 1 to 2 feet per second and the room took a few minutes to completely clear the visible smoke.

Additional large area smoke testing was conducted in support of the AFCI glovebox testing and recovery project. Unexpected airflow patterns were observed in the immediate vicinity of the glovebox and at the top of the room near the ceiling however the general room airflow headed towards the exhaust. Overall general airflow patterns are the same in that it travels towards the room exhaust on the west side as expected; however there were several eddy currents identified in the immediate vicinity of the glovebox and in some places there was quite a bit of lift towards the ceiling.

The fixed Alpha 7A CAM sampling head is located near the room exhaust by the top of the door at the southwest side of the room. This CAM performed well in this location during airborne releases that occurred (under controlled conditions) during recovery testing. In addition, FASS heads are located throughout the room.

\subsection{Surface Contamination Surveys Evaluation}

No surface contamination above LRD-15001 Table 2-2 limits was found in the AFCI enclosure during the event timeframe. During glovebox component testing, the only surface contamination identified was on the oxygen analyzer. No surface contamination was found during the subsequent arc melter run prior to glovebox system repairs. Multiple types of media were used for surface contamination surveys during testing to ensure there were not unique material properties that prevented the contamination from adhering to the surface. Smears were attempted using the same membrane air filter media (Millipore) used in the CAMs/air samplers since the Am-241 adhered to it during the releases.

The AFCI glovebox is used to produced transmutation fuel samples (which include americium) through arc melting and to purify metallic americium through the americium distillation operation. Although the distillation process is a closed system the arc melting process is open to the glovebox atmosphere.

Americium has a very high vapor pressure and as such during these operations, particularly arc melting, it is likely that some small amount of americium is volatilized and is spread into the glovebox atmosphere. The high vapor pressure of americium is unique among the actinide materials therefore the transport of the metallic sub-micron sized particles is not well known or documented. It is suspected that the small leak points in the glovebox confinement system allowed the americium metallic sub-micron sized particles to escape but did not allow other forms of contamination to escape under other operating conditions. It is also suspected that the sub-micron sized particles remained airborne and were pulled into the AFCI enclosure exhaust ventilation. 


\section{Lessons Learned}

\subsection{AFCI Glovebox}

- Glovebox support systems that are part of the confinement barrier should be evaluated for equipment wear and failure (as demonstrated by metal fatigue with the bellows pumps in this case).

- Helium leak testing proved to be an effective tool in identifying equipment degradation while maintaining the glovebox atmosphere at a slight negative pressure for contamination control.

\subsection{Alpha 7A CAMs}

A lessons learned ${ }^{28}$ on the Alpha 7 CAM performance was submitted to the OPEXShare site and is summarized below:

- Facilities that have source terms with multiple isotopes or changing radionuclide compositions should consider configuring the Alpha 7A as a pseudo region of interest CAM rather than selecting a few dose isotopes for measurement.

- The contamination profile (radionuclide ratios) in confinement systems may shift significantly from the expected when multiple processes are present.

- Air filter analysis using another instrument should be conducted on air filter associated with maintenance and failure alarms on CAMs.

- Instruments running proprietary software should be evaluated with caution to identify limitations.

- The Alpha 7A CAM has extensive data logging capabilities. The electronic data provided by the CAM was valuable in event reconstruction using published curve fitting techniques. Even though the configuration was not optimum for rapid detection during the release, the amount of raw spectrum data available was sufficient to identify multiple low level releases, their duration, and approximate magnitudes. 


\section{References}

1. SAR-404, "Safety Analysis Report for the Fuel Manufacturing Facility," Rev. 3, May 2013

2. “Official FMF Logbook," July 1, 2014 to April 2, 2015

3. LOG-FMF-A, “Operations Log TSR Related,” Rev. 34, May 5, 2014 to July 3, 2014

4. Radiological Controls Electronic Logs (various), from August 25, 2014 to September 3, 2014

5. Critique Report, "MFC-704 FMF Suspect Contamination Found on CAM Filters," Fact Finding 9/30/2014, report date10/2/2014

6. PLN-4861, “AFCI Glovebox Testing Plan,” Rev. 0, February 2015

7. INL/MIS-14-33725, "Materials \& Fuels Complex Fuel Manufacturing Facility Advanced Fuel Cycle Initiative Room Low Level Airborne Release August 2014,” BEA Office of Nuclear Assurance, November 2014

8. W7040-0196-ES, “AFCI (Advanced Fuel Cycle Initiative) Glovebox Design, Fabrication \& Installation Description, Revision 5, February 2010

9. DOE-STD-1128, Department of Energy Standard - Good Practices for Occupational Radiological Protection in Plutonium Facilities, April 2013

10. LOG-FMF-A, "Operations LOG TSR Related/PTC Related," Rev. 36, completed forms from $8 / 25 / 2014$ to $9 / 8 / 2014$

11. LI-692, “AFCI Glovebox Component Testing and Surveys,” Rev. 2, January 2015

12. INL/INT-14-00118, "Alpha 7A Continuous Air Monitor Data Reconstruction for Advanced Fuel Cycle Initiative Glovebox Airborne Radioactivity Release," Rev. 0, Kevin Kozen, Rebecca Case, Lawrence Burke, Bradley Schraeder, December 2014

13. MCP-139, "Radiological Surveys,” Rev. 19, March 2015.

14. LRD-15001, "Radiological Control Manual,” Rev. 5, March 2015

15. MCP-352, "Radiological Air Monitoring Requirements, Rev. 8, April 2014 and Rev. 9, July 2015.

16. LI-598, "Performing Radiological Air Monitoring," Rev. 1, August 2014 and Rev. 2, July 2015.

17. TPR-13438, “Leak Test Procedure,” Rev. 1, June 2012

18. FMF-OI-607, “AFCI Glovebox Equipment Operations,” Rev. 19, August 2014

19. RCE-FMF-2015-17, INL Radiological Control Evaluation Form 441.A81, December 1, 2015

20. ECAR-897, "Radiological Air Monitoring Evaluation for MFC-704, Fuel Manufacturing Facility,” Rev. 2, September 2013 
21. TPR-7638, "Eberline Alpha 7A CAM Operation and Performance Checks,” Rev. 6, April 2014

22. LWP-15015, "Response to Abnormal Radiological Conditions," Rev. 6, September 2013

23. ECAR-127, "Determine Proper Placement of Routine Air Samplers and CAMs, and Establish CAM Alarm Settings," Rev. 6, March 2015

24. TEV-2423, “Alpha 7A CAM Version 2.2.0.2,” Rev. 0, August, 2015

25. PDD-15001, “Air Monitoring Technical Basis Document,” Rev.1 , August 2015

26. TPR-7638, "Eberline Alpha 7A CAM Operation and Performance Checks," Rev. 8, November 2015

27. ECAR-2344, "Facility Basis Document for Radiological Monitoring - Fuel Manufacturing facility (FMF) MFC-704,” Rev. 0, September 2015

28. Lessons Learned, OPEXShare, "Continuous Air Monitor did not Perform as Expected," January 21, 2015, https://opexshare.doe.gov/lesson.cfm/2015/1/21/4732/Continuous-AirMonitor-did-not-Perform-as-Expected 


\section{Appendix A - Glovebox Tests or Activities, Results, and Conclusions}

Red text $=$ radiological contamination identified

Bold text $=$ confirmation corrective actions were effective

Tests or activities are listed chronologically based on finish date.

\begin{tabular}{|c|c|c|c|c|c|c|c|}
\hline$\overline{\text { Date }}$ & \multicolumn{3}{|c|}{ Test or Activity } & Summary of Results & $\begin{array}{c}\text { Rad Con } \\
\text { Contamination } \\
\text { Survey Results }\end{array}$ & $\begin{array}{l}\text { Rad Con Air Filter } \\
\text { Survey Results } \\
\text { (Delayed Count) }^{\mathrm{a}}\end{array}$ & Conclusions \\
\hline $12 / 17 / 14$ & $\begin{array}{l}\text { Glovebox } \\
\text { Component } \\
\text { Testing } \\
\text { (LI-692) }\end{array}$ & $\begin{array}{l}\text { Smoke Test of } \\
\text { AFCI Enclosure }\end{array}$ & $\begin{array}{l}\text { Used smoke generators to } \\
\text { determine direction/speed } \\
\text { airborne contamination would } \\
\text { travel. }\end{array}$ & $\begin{array}{l}\text { Smoke was released in various } \\
\text { locations around the AFCI } \\
\text { glovebox. The general } \\
\text { enclosure airflow headed west } \\
\text { towards the exhaust and fixed } \\
\text { CAM with some unexpected } \\
\text { airflow patterns in the } \\
\text { immediate vicinity of the } \\
\text { glovebox and at the top of the } \\
\text { room. The longest travel time } \\
\text { to the fixed CAM was } 1 \text { minute } \\
46 \text { seconds. }\end{array}$ & NA & NA & $\begin{array}{l}\text { The fixed CAM sampling } \\
\text { head (located near the room } \\
\text { exhaust) is appropriately } \\
\text { located. }\end{array}$ \\
\hline $1 / 14 / 15$ & $\begin{array}{l}\text { Glovebox } \\
\text { Component } \\
\text { Testing } \\
\text { (LI-692) }\end{array}$ & $\begin{array}{l}\text { Oil Sample from } \\
\text { Gas Exhaust } \\
\text { System Vacuum } \\
\text { Pump (V3-PMP- } \\
\text { 114) }\end{array}$ & $\begin{array}{l}\text { Sampled vacuum pump (V3- } \\
\text { PMP-114) oil to identify } \\
\text { presence of any radiological } \\
\text { material passing through } \\
\text { exhaust system for the arc } \\
\text { melter and americium } \\
\text { distillation furnace. }\end{array}$ & $\begin{array}{l}\text { No contamination was } \\
\text { identified in the oil sample } \\
\text { above detection limits from } \\
\text { gamma spectroscopy and liquid } \\
\text { scintillation (gross alpha/beta). }\end{array}$ & $\begin{array}{l}\text { No surface } \\
\text { contamination } \\
\text { above LRD-15001 } \\
\text { Table 2-2 limits }\end{array}$ & $\begin{array}{l}\text { Less than MDA } \\
\text { (iSolo) }\end{array}$ & $\begin{array}{l}\text { Does not indicate Am-241 } \\
\text { contamination is passing } \\
\text { through arc melter and } \\
\text { americium distillation } \\
\text { furnace exhaust system. }\end{array}$ \\
\hline $1 / 14 / 15$ & $\begin{array}{l}\text { Glovebox } \\
\text { Component } \\
\text { Testing } \\
\text { (LI-692) }\end{array}$ & $\begin{array}{l}\text { Gamma-Ray } \\
\text { Detection }\end{array}$ & $\begin{array}{l}\text { Used gamma-ray } \\
\text { spectrometry equipment to } \\
\text { count the glovebox filter (V3- } \\
\text { FLTR-114) for the exhaust } \\
\text { system to the arc melter and } \\
\text { americium distillation } \\
\text { furnace. }\end{array}$ & $\begin{array}{l}\text { No Am- } 241 \text { was detectable in } \\
\text { the filter. }\end{array}$ & $\mathrm{NA}$ & NA & $\begin{array}{l}\text { Does not indicate Am-241 } \\
\text { contamination captured in } \\
\text { the filter for the arc melter } \\
\text { and americium distillation } \\
\text { furnace exhaust system. }\end{array}$ \\
\hline $1 / 20 / 15$ & $\begin{array}{l}\text { Glovebox } \\
\text { Component } \\
\text { Testing } \\
\text { (LI-692) } \\
\end{array}$ & $\begin{array}{l}\text { Glove } \\
\text { Replacement } \\
\text { without Items } \\
\text { Transferred In } \\
\end{array}$ & $\begin{array}{l}\text { Changed out a glove (WA- } \\
25 \text { ) and surveyed area around } \\
\text { glove for contamination. }\end{array}$ & The glove was changed. & $\begin{array}{l}\text { No surface } \\
\text { contamination } \\
\text { above LRD-15001 } \\
\text { Table 2-2 limits } \\
\end{array}$ & $\begin{array}{l}\text { Less than MDA } \\
\text { (iSolo) }\end{array}$ & $\begin{array}{l}\text { Does not indicate } \\
\text { contamination is escaping } \\
\text { from the gloveport. }\end{array}$ \\
\hline
\end{tabular}

a Delayed counts are typically performed 7 days or more from sample acquisition. Air filter surveys for the job-specific and investigative CAMs/air samplers were performed using either the Canberra iSolo alpha/beta counter or the Ludlum 3030 alpha/beta counter. The iSolo counter automatically adjusts results to remove radon/thoron progeny from the results. The 3030 counter does not. Both counts are adjusted for background. See Section 5.1 for a discussion on MDA. 


\begin{tabular}{|c|c|c|c|c|c|c|c|}
\hline Date & \multicolumn{3}{|c|}{ Test or Activity } & Summary of Results & $\begin{array}{c}\text { Rad Con } \\
\text { Contamination } \\
\text { Survey Results } \\
\end{array}$ & $\begin{array}{l}\text { Rad Con Air Filter } \\
\text { Survey Results } \\
\text { (Delayed Count) }^{\mathrm{a}}\end{array}$ & Conclusions \\
\hline $1 / 21 / 15$ & $\begin{array}{l}\text { Glovebox } \\
\text { Component } \\
\text { Testing } \\
\text { (LI-692) }\end{array}$ & $\begin{array}{l}\text { Glove } \\
\text { Replacement with } \\
\text { Items Transferred } \\
\text { In }\end{array}$ & $\begin{array}{l}\text { Changed out a glove (WA- } \\
\text { 25) while transferring tools } \\
\text { into the glovebox and } \\
\text { surveyed area around glove } \\
\text { for contamination. }\end{array}$ & $\begin{array}{l}\text { Some wrinkles and } \\
\text { deformation were seen on the } \\
\text { glove. }\end{array}$ & $\begin{array}{l}\text { No surface } \\
\text { contamination } \\
\text { above LRD-15001 } \\
\text { Table 2-2 limits }\end{array}$ & $\begin{array}{l}\text { Less than MDA } \\
\text { (iSolo) }\end{array}$ & $\begin{array}{l}\text { Does not indicate } \\
\text { contamination is escaping } \\
\text { from the gloveport. }\end{array}$ \\
\hline $1 / 27 / 15$ & $\begin{array}{l}\text { Glovebox } \\
\text { Component } \\
\text { Testing } \\
\text { (LI-692) }\end{array}$ & $\begin{array}{l}\text { Internal Glove } \\
\text { Inspections }\end{array}$ & $\begin{array}{l}\text { Inspected "used" gloves, O- } \\
\text { rings, and CLR support rings } \\
\text { for leak points. }\end{array}$ & $\begin{array}{l}\text { Visible deformations (divots } \\
\text { with little wrinkles) were seen } \\
\text { on gloves but no holes were } \\
\text { identified. No deformations } \\
\text { were seen on O-rings and CLR } \\
\text { support rings. }\end{array}$ & $\begin{array}{l}\text { No surface } \\
\text { contamination } \\
\text { above LRD-15001 } \\
\text { Table 2-2 limits }\end{array}$ & $\begin{array}{l}\text { Less than MDA } \\
\text { (iSolo) }\end{array}$ & $\begin{array}{l}\text { Does not indicate } \\
\text { contamination is escaping } \\
\text { through gloves. }\end{array}$ \\
\hline $1 / 28 / 15$ & $\begin{array}{l}\text { Glovebox } \\
\text { Component } \\
\text { Testing } \\
\text { (LI-692) }\end{array}$ & $\begin{array}{l}\text { Americium } \\
\text { Distillation } \\
\text { Furnace Exhaust } \\
\text { Line Integrity } \\
\text { Checks }\end{array}$ & $\begin{array}{l}\text { Drew a vacuum on the } \\
\text { exhaust line for the } \\
\text { americium distillation furnace } \\
\text { and monitored loss of vacuum } \\
\text { over time. }\end{array}$ & $\begin{array}{l}\text { Test } \# 1 \text { - Line was isolated at } \\
750 \text { millitorr and reached } \\
\text { atmospheric pressure in } 14 \\
\text { minutes. } \\
\text { Test } \# 2 \text { - Line was isolated at } \\
400 \text { millitorr and reached } \\
\text { atmospheric pressure in } 17 \\
\text { minutes. }\end{array}$ & $\begin{array}{l}\text { No surface } \\
\text { contamination } \\
\text { above LRD-15001 } \\
\text { Table 2-2 limits }\end{array}$ & $\begin{array}{l}\text { Less than MDA } \\
\text { (iSolo) }\end{array}$ & $\begin{array}{l}\text { In conjunction with leak test } \\
\text { performed on } 8 / 17 / 15 \text {, } \\
\text { indicated leakage through } \\
\text { valves internal to exhaust } \\
\text { system only. }\end{array}$ \\
\hline $1 / 29 / 15$ & $\begin{array}{l}\text { Glovebox } \\
\text { Component } \\
\text { Testing } \\
\text { (LI-692) }\end{array}$ & $\begin{array}{l}\text { Arc Melter } \\
\text { Exhaust Line } \\
\text { Integrity Checks }\end{array}$ & $\begin{array}{l}\text { Drew a vacuum on the } \\
\text { exhaust line for the arc melter } \\
\text { and monitored loss of vacuum } \\
\text { over time. }\end{array}$ & $\begin{array}{l}\text { Line was isolated at } 350 \\
\text { millitorr and reached } \\
\text { atmospheric pressure in } 9 \\
\text { minutes }\end{array}$ & $\begin{array}{l}\text { No surface } \\
\text { contamination } \\
\text { above LRD-15001 } \\
\text { Table 2-2 limits }\end{array}$ & $\begin{array}{l}\text { Less than MDA } \\
\text { (iSolo) }\end{array}$ & $\begin{array}{l}\text { In conjunction with leak test } \\
\text { performed on } 8 / 17 / 15 \text {, } \\
\text { indicated leakage through } \\
\text { valves internal to exhaust } \\
\text { system only. }\end{array}$ \\
\hline $2 / 3 / 15$ & $\begin{array}{l}\text { Glovebox } \\
\text { Component } \\
\text { Testing } \\
\text { (LI-692) }\end{array}$ & $\begin{array}{l}\text { Secondary } \\
\text { Pressure Control } \\
\text { Component } \\
\text { Checks }\end{array}$ & $\begin{array}{l}\text { Actuated the secondary } \\
\text { pressure control system (by } \\
\text { glove manipulation) and } \\
\text { surveyed secondary exhaust } \\
\text { piping and equipment for } \\
\text { contamination. }\end{array}$ & $\begin{array}{l}\text { Secondary pressure control } \\
\text { system was actuated six times. }\end{array}$ & $\begin{array}{l}\text { No surface } \\
\text { contamination } \\
\text { above LRD-15001 } \\
\text { Table 2-2 limits }\end{array}$ & $\begin{array}{l}\text { Less than MDA } \\
\text { (iSolo) }\end{array}$ & $\begin{array}{l}\text { Does not indicate } \\
\text { contamination is escaping } \\
\text { from the secondary pressure } \\
\text { control exhaust system. }\end{array}$ \\
\hline $2 / 4 / 15$ & $\begin{array}{l}\text { Glovebox } \\
\text { Component } \\
\text { Testing } \\
\text { (LI-692) }\end{array}$ & $\begin{array}{l}\text { Purification Bed } \\
\text { Exchange Checks }\end{array}$ & $\begin{array}{l}\text { Switched purification beds } \\
\text { and surveyed purification } \\
\text { system for contamination. }\end{array}$ & $\begin{array}{l}\text { The beds were switched from } \\
\text { bed } \# 1 \text { to bed } \# 2 \text {. }\end{array}$ & $\begin{array}{l}\text { No surface } \\
\text { contamination } \\
\text { above LRD-15001 } \\
\text { Table 2-2 limits }\end{array}$ & $\begin{array}{l}\text { Less than MDA } \\
\text { (iSolo) }\end{array}$ & $\begin{array}{l}\text { Does not indicate } \\
\text { contamination is escaping } \\
\text { from through the purification } \\
\text { system. }\end{array}$ \\
\hline $\begin{array}{l}2 / 10 / 15 \\
\text { (start) } \\
2 / 23 / 15 \\
\text { (finish) }\end{array}$ & $\begin{array}{l}\text { Glovebox } \\
\text { Component } \\
\text { Testing } \\
\text { (LI-692) }\end{array}$ & $\begin{array}{l}\text { Oxygen Analyzer } \\
\text { Operations }\end{array}$ & $\begin{array}{l}\text { Manipulated the oxygen } \\
\text { analyzer system and surveyed } \\
\text { system for contamination. } \\
\text { Sampled oxygen analyzer } \\
\text { (AHe-AE-034) electrolyte } \\
\text { fluid for contamination. }\end{array}$ & $\begin{array}{l}\text { Oxygen analyzers were } \\
\text { swapped, shut down, and } \\
\text { restarted twice. } \\
\text { Liquid scintillation counting } \\
\text { identified } 4.4 \mathrm{E}+1 \mathrm{dpm} / \mathrm{ml} \text { of } \\
\text { gross beta with no gross alpha } \\
\text { contamination above detection } \\
\text { limits. }\end{array}$ & $\begin{array}{l}\text { Test \#1 \& \#2 } \\
\text { - No surface } \\
\text { contamination } \\
\text { above LRD- } \\
15001 \text { Table } \\
2-2 \text { limits }\end{array}$ & $\begin{array}{l}\text { Test \#1 } \\
\text { - CAM “poor fit" alarm } \\
\text { - Up to } 56 \mathrm{dpm} \text { alpha } \\
\text { and } 16.4 \mathrm{dpm} \text { beta } \\
\text { Test \#2 } \\
\text { - Up to } 1.2 \mathrm{dpm} \text { alpha } \\
\text { and } 26.0 \mathrm{dpm} \text { beta } \\
\text { (iSolo) }\end{array}$ & $\begin{array}{l}\text { Indicates contamination is } \\
\text { escaping through the oxygen } \\
\text { analyzer system. }\end{array}$ \\
\hline
\end{tabular}




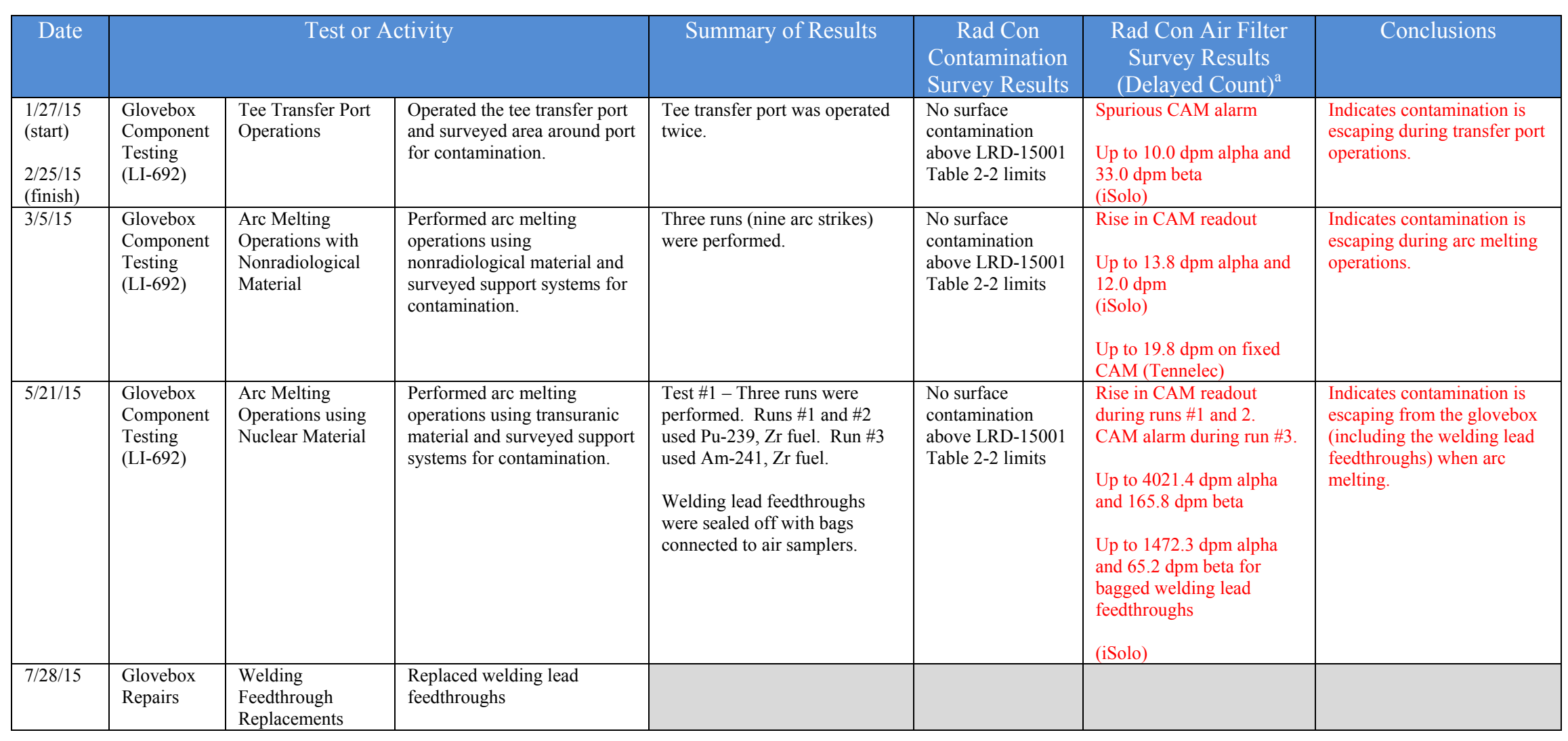




\begin{tabular}{|c|c|c|c|c|c|c|c|}
\hline Date & \multicolumn{3}{|c|}{ Test or Activity } & Summary of Results & Rad Con & Rad Con Air Filter & Conclusions \\
\hline $7 / 28 / 15$ & $\begin{array}{l}\text { Helium } \\
\text { Leak } \\
\text { Testing }\end{array}$ & $\begin{array}{l}\text { Helium Leak Test } \\
\# 1\end{array}$ & $\begin{array}{l}\text { Introduced helium into the } \\
\text { glovebox while maintaining a } \\
\text { slight negative pressure and } \\
\text { checked for helium outside } \\
\text { the glovebox. }\end{array}$ & $\begin{array}{l}\text { Helium was detected around } \\
\text { the following: } \\
\text { - Bellows pump (AHe- } \\
\text { PMP-055) for the oxygen } \\
\text { analyzer (AHe-AE-034) } \\
\text { KF flange on the exhaust } \\
\text { line to the bellows pump } \\
\text { (AHe-PMP-055) } \\
\text { - Lower intake fitting of the } \\
\text { oxygen analyzer (AHe- } \\
\text { AE-034) } \\
\text { - Filter housing in pressure } \\
\text { control cabinet. } \\
\text { Helium was also detected } \\
\text { around the HEPA filter } \\
\text { housing for the glovebox } \\
\text { suspect exhaust header. } \\
\text { No leaks were detected at the } \\
\text { welding feedthroughs. }\end{array}$ & & & $\begin{array}{l}\text { Indicates confinement } \\
\text { breaches for the areas noted. } \\
\text { Determined no leaks for the } \\
\text { HEPA filter housing. } \\
\text { Indicates normal permeation } \\
\text { of helium through the gasket } \\
\text { over time. }\end{array}$ \\
\hline $8 / 11 / 15$ & $\begin{array}{l}\text { Glovebox } \\
\text { Repairs }\end{array}$ & $\begin{array}{l}\text { Various AFCI } \\
\text { Glovebox } \\
\text { Component } \\
\text { Repairs }\end{array}$ & $\begin{array}{l}\text { Replaced bellows pumps, O- } \\
\text { rings on KF flange, and } \\
\text { tighten lower intake fitting } \\
\text { and filter housing. }\end{array}$ & & & & \\
\hline $8 / 17 / 15$ & $\begin{array}{l}\text { Helium } \\
\text { Leak } \\
\text { Testing }\end{array}$ & $\begin{array}{l}\text { Helium Leak Test } \\
\# 2\end{array}$ & $\begin{array}{l}\text { Introduced helium into the } \\
\text { glovebox while maintaining a } \\
\text { slight negative pressure and } \\
\text { checked for helium outside } \\
\text { the glovebox. }\end{array}$ & $\begin{array}{l}\text { Helium was detected around } \\
\text { the following: } \\
\text { - Fitting on exhaust line to } \\
\text { oxygen analyzer (AHe- } \\
\text { AE-034) } \\
\text { - Fitting on eight way valve } \\
\text { (AHe-MV-001). } \\
\text { No helium was detected at the } \\
\text { welding feedthroughs, } \\
\text { americium distillation furnace } \\
\text { exhaust line, or arc melter } \\
\text { exhaust line. }\end{array}$ & & & $\begin{array}{l}\text { Indicates confinement } \\
\text { breaches for the areas noted. } \\
\text { Indicates no leaks for the } \\
\text { welding feedthroughs } \\
\text { following replacement and } \\
\text { no leaks for the exhaust } \\
\text { lines. }\end{array}$ \\
\hline $\begin{array}{l}8 / 17 / 15 \\
8 / 24 / 15\end{array}$ & $\begin{array}{l}\text { Glovebox } \\
\text { Repairs }\end{array}$ & $\begin{array}{l}\text { Various AFCI } \\
\text { Glovebox } \\
\text { Component } \\
\text { Repairs }\end{array}$ & $\begin{array}{l}\text { Repaired/tightened fitting on } \\
\text { exhaust line and eight way } \\
\text { valve. }\end{array}$ & & $\begin{array}{l}43 \mathrm{dpm} / 100 \mathrm{~cm} 2 \\
\text { on eight way valve } \\
\text { prior to leak test } \\
\text { (decontaminated) }\end{array}$ & & \\
\hline
\end{tabular}




\begin{tabular}{|c|c|c|c|c|c|c|c|}
\hline$\overline{\text { Date }}$ & \multicolumn{3}{|c|}{ Test or Activity } & Summary of Results & Rad Con & Rad Con Air Filter & $\overline{\text { Conclusions }}$ \\
\hline $8 / 24 / 15$ & $\begin{array}{l}\text { Helium } \\
\text { Leak } \\
\text { Testing }\end{array}$ & $\begin{array}{l}\text { Helium Leak Test } \\
\# 3\end{array}$ & $\begin{array}{l}\text { Introduced helium into the } \\
\text { glovebox while maintaining a } \\
\text { slight negative pressure and } \\
\text { checked for helium outside } \\
\text { the glovebox. }\end{array}$ & $\begin{array}{l}\text { No helium was detected } \\
\text { outside the glovebox. }\end{array}$ & & & $\begin{array}{l}\text { Confirms glovebox } \\
\text { component repairs were } \\
\text { successful. }\end{array}$ \\
\hline $8 / 26 / 15$ & $\begin{array}{l}\text { Glovebox } \\
\text { Component } \\
\text { Testing } \\
\text { (LI-692) }\end{array}$ & $\begin{array}{l}\text { Arc Melting } \\
\text { Operations using } \\
\text { Nuclear Material }\end{array}$ & $\begin{array}{l}\text { Performed arc melting } \\
\text { operations using transuranic } \\
\text { material and surveyed support } \\
\text { systems for contamination. }\end{array}$ & $\begin{array}{l}\text { Test } \# 2 \text { - Three runs were } \\
\text { performed. Run } \# 1 \text { used Zr. } \\
\text { Runs } \# 2 \text { and } \# 3 \text { used Am-241, } \\
\text { Zr fuel. }\end{array}$ & $\begin{array}{l}\text { No surface } \\
\text { contamination } \\
\text { above LRD-15001 } \\
\text { Table 2-2 limits }\end{array}$ & $\begin{array}{l}\text { Less than MDA } \\
\text { (Ludlum 3030) }\end{array}$ & \\
\hline $9 / 2 / 15$ & $\begin{array}{l}\text { Glovebox } \\
\text { Component } \\
\text { Testing } \\
\text { (LI-692) }\end{array}$ & $\begin{array}{l}\text { Arc Melting } \\
\text { Operations using } \\
\text { Nuclear Material }\end{array}$ & $\begin{array}{l}\text { Performed arc melting } \\
\text { operations using transuranic } \\
\text { material and surveyed support } \\
\text { systems for contamination. } \\
\text { Note - purification beds and } \\
\text { oxygen monitors were } \\
\text { switched between runs. }\end{array}$ & $\begin{array}{l}\text { Test \#3 - Four runs were } \\
\text { performed. Runs \#1 through } \\
\# 4 \text { used Am-241, Zr fuel. }\end{array}$ & $\begin{array}{l}\text { No surface } \\
\text { contamination } \\
\text { above LRD-15001 } \\
\text { Table 2-2 limits }\end{array}$ & $\begin{array}{l}\text { Less than MDA } \\
\text { (Ludlum 3030) }\end{array}$ & $\begin{array}{l}\text { Confirms glovebox } \\
\text { confinement is repaired to } \\
\text { support arc melting and } \\
\text { tee transfer port } \\
\text { operations. }\end{array}$ \\
\hline $11 / 2 / 15$ & $\begin{array}{l}\text { Research } \\
\text { Operations }\end{array}$ & $\begin{array}{l}\text { Arc Melting } \\
\text { Operation \#1 }\end{array}$ & $\begin{array}{l}\text { Performed arc melting } \\
\text { operations using Du, Zr and } \\
\text { surveyed support systems for } \\
\text { contamination. (Note a) }\end{array}$ & $\begin{array}{l}\text { Six button casts and one drop } \\
\text { cast performed. }\end{array}$ & $\begin{array}{l}\text { No surface } \\
\text { contamination } \\
\text { above LRD-15001 } \\
\text { Table 2-2 limits }\end{array}$ & $\begin{array}{l}\text { Less than MDA } \\
\text { (Ludlum 3030) }\end{array}$ & \\
\hline $11 / 3 / 15$ & $\begin{array}{l}\text { Research } \\
\text { Operations }\end{array}$ & $\begin{array}{l}\text { Arc Melting } \\
\text { Operation \#2 }\end{array}$ & $\begin{array}{l}\text { Performed arc melting } \\
\text { operations using Pu-239, } \mathrm{Zr} \\
\text { and surveyed support systems } \\
\text { for contamination. (Note a) }\end{array}$ & $\begin{array}{l}\text { Three button casts and one } \\
\text { drop cast performed. }\end{array}$ & $\begin{array}{l}\text { No surface } \\
\text { contamination } \\
\text { above LRD-15001 } \\
\text { Table 2-2 limits } \\
\end{array}$ & $\begin{array}{l}\text { Less than MDA } \\
\text { (Ludlum 3030) }\end{array}$ & \\
\hline $11 / 4 / 15$ & $\begin{array}{l}\text { Research } \\
\text { Operations }\end{array}$ & $\begin{array}{l}\text { Arc Melting } \\
\text { Operation \#3 }\end{array}$ & $\begin{array}{l}\text { Performed arc melting } \\
\text { operations using Du, } \mathrm{Zr} \text { and } \\
\text { surveyed support systems for } \\
\text { contamination. (Note a) }\end{array}$ & $\begin{array}{l}\text { Six button casts and two drop } \\
\text { casts performed. }\end{array}$ & $\begin{array}{l}\text { No surface } \\
\text { contamination } \\
\text { above LRD-15001 } \\
\text { Table 2-2 limits }\end{array}$ & $\begin{array}{l}\text { Less than MDA } \\
\text { (Ludlum 3030) }\end{array}$ & \\
\hline $11 / 5 / 15$ & $\begin{array}{l}\text { Research } \\
\text { Operations }\end{array}$ & $\begin{array}{l}\text { Arc Melting } \\
\text { Operation \#4 }\end{array}$ & $\begin{array}{l}\text { Performed arc melting } \\
\text { operations using } \mathrm{Du}, \mathrm{Zr} \text { and } \\
\text { surveyed support systems for } \\
\text { contamination. (Note a) }\end{array}$ & $\begin{array}{l}\text { Twelve button casts and five } \\
\text { drop casts performed. }\end{array}$ & $\begin{array}{l}\text { No surface } \\
\text { contamination } \\
\text { above LRD-15001 } \\
\text { Table 2-2 limits } \\
\end{array}$ & $\begin{array}{l}\text { Less than MDA } \\
\text { (Ludlum 3030) }\end{array}$ & \\
\hline $11 / 10 / 15$ & $\begin{array}{l}\text { Research } \\
\text { Operations }\end{array}$ & $\begin{array}{l}\text { Arc Melting } \\
\text { Operation \#5 }\end{array}$ & $\begin{array}{l}\text { Performed arc melting } \\
\text { operations using Du, } \mathrm{Zr} \text { and } \\
\mathrm{Am}-241, \mathrm{Zr} \text { and surveyed } \\
\text { support systems for } \\
\text { contamination. (Note a) }\end{array}$ & $\begin{array}{l}\text { Two button casts and } 3 \text { drop } \\
\text { casts on } \mathrm{Du}, \mathrm{Zr} \text { material } \\
\text { performed. } \\
\text { One button cast and two drop } \\
\text { casts on Am, } \mathrm{Zr} \text { material } \\
\text { performed. }\end{array}$ & $\begin{array}{l}\text { No surface } \\
\text { contamination } \\
\text { above LRD-15001 } \\
\text { Table 2-2 limits }\end{array}$ & $\begin{array}{l}\text { Less than MDA } \\
\text { (Ludlum 3030) }\end{array}$ & \\
\hline
\end{tabular}




\section{Appendix B - AFCI Glovebox Components Identified During Helium Leak Testing}

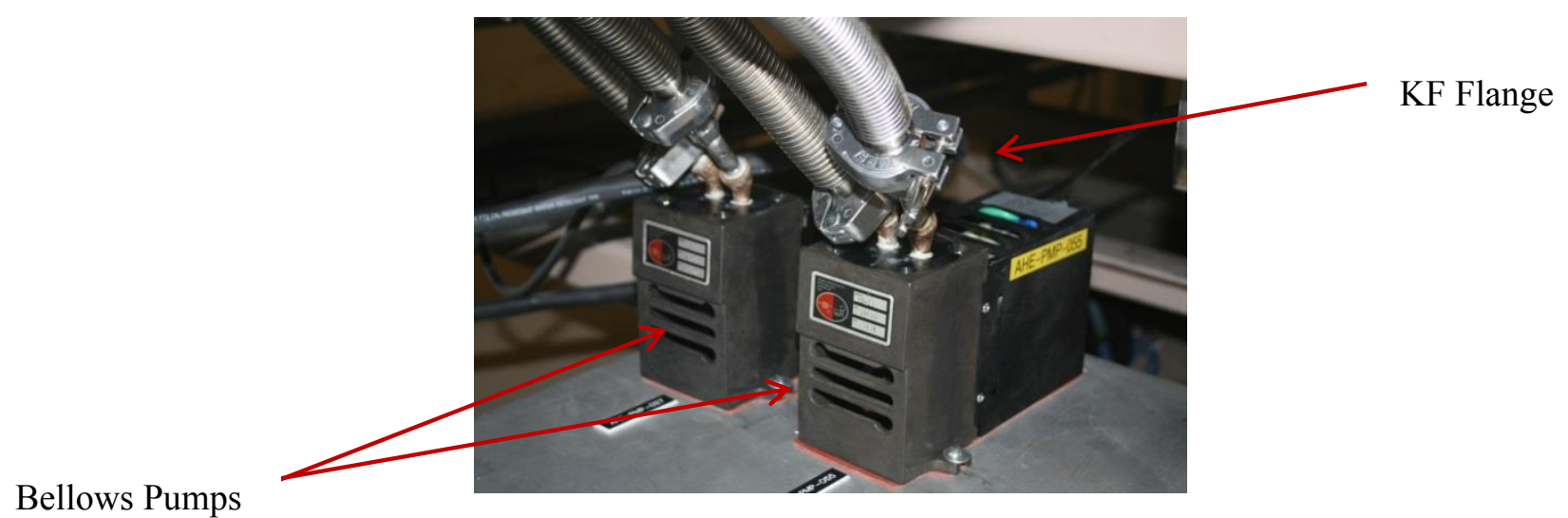

Bellows Pumps for Oxygen Analyzers
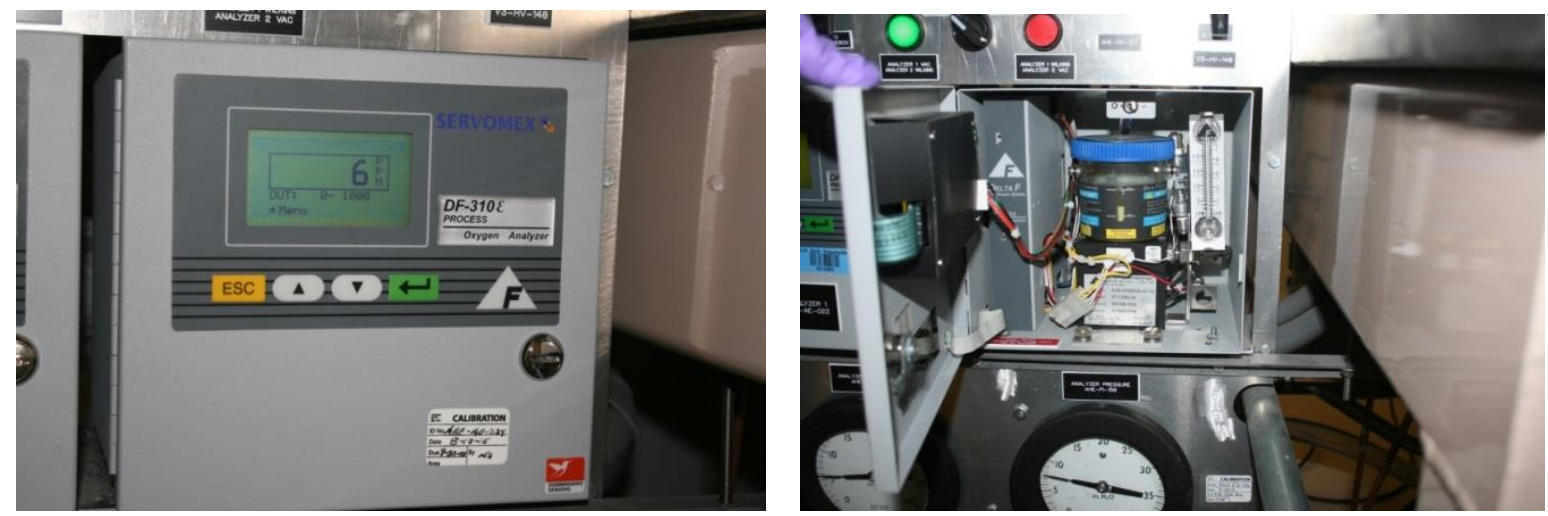

Oxygen Analyzer (AHe-AE-034) - front view with panel closed and open
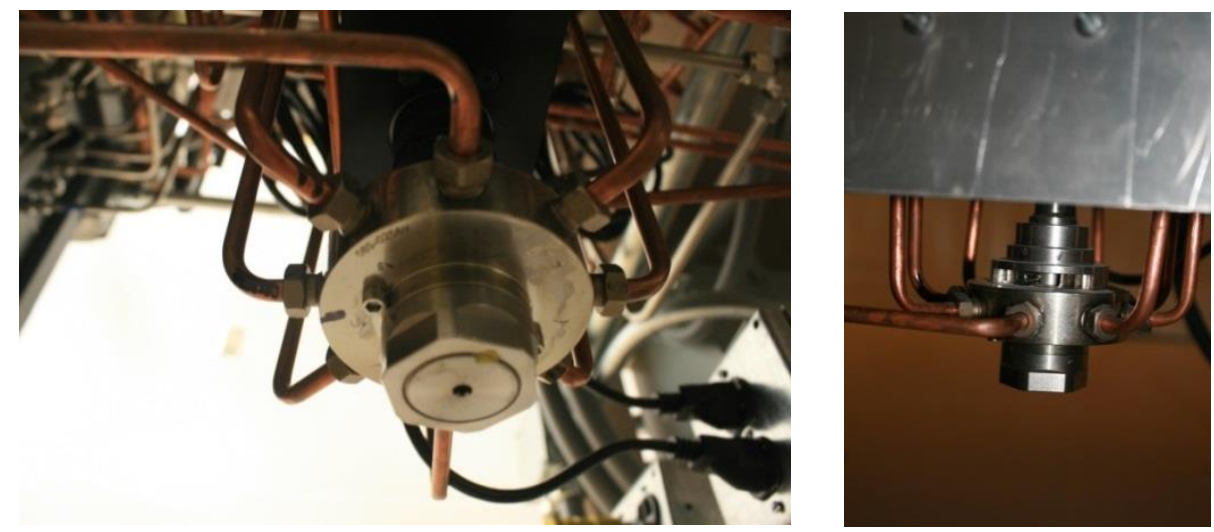

8-Way Valve for Oxygen Analyzer System 


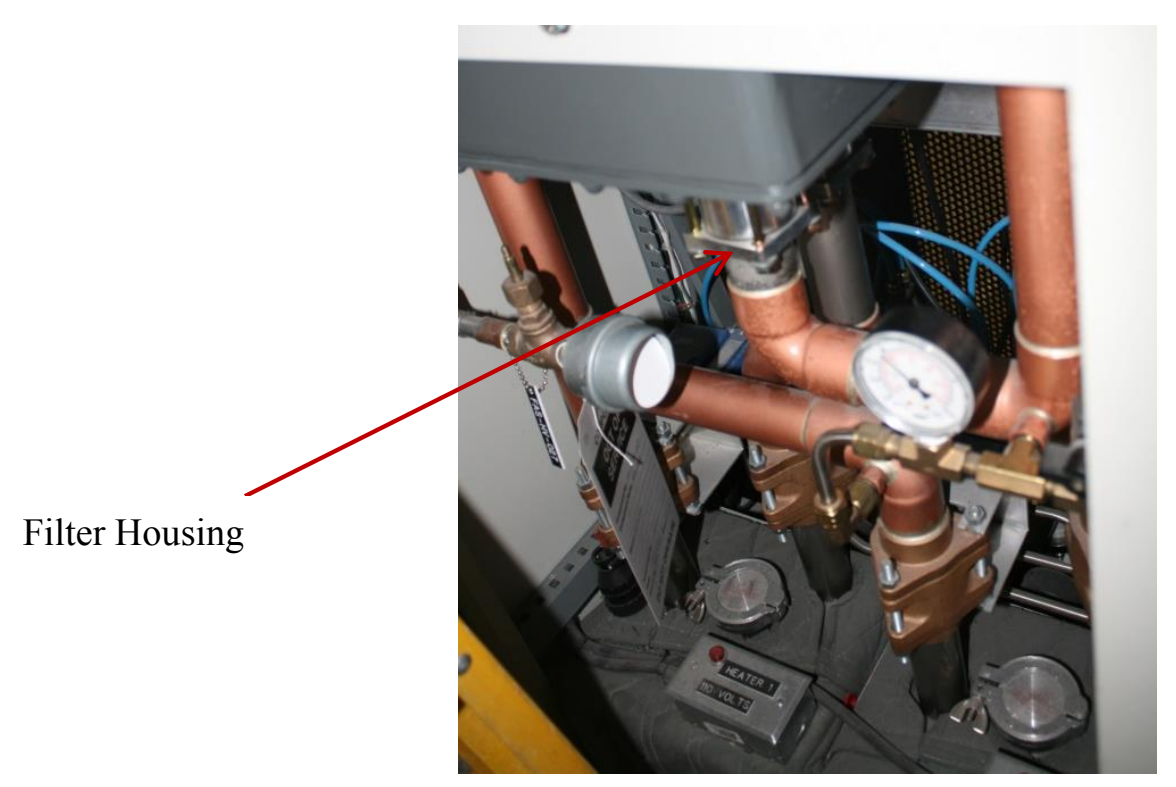

Filter Housing in Pressure Control Cabinet 